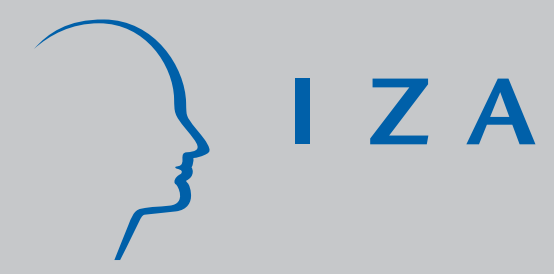

IZADP No. 2265

Phillips Curves and Unemployment Dynamics: A Critique and a Holistic Perspective

Marika Karanassou

Hector Sala

Dennis J. Snower

August 2006 


\title{
Phillips Curves and Unemployment Dynamics: A Critique and a Holistic Perspective
}

\author{
Marika Karanassou \\ Queen Mary, University of London \\ and IZA Bonn \\ Hector Sala \\ Universitat Autònoma de Barcelona \\ and IZA Bonn \\ Dennis J. Snower \\ Kiel Institute for World Economics, \\ University of Kiel, CEPR and IZA Bonn
}

Discussion Paper No. 2265

August 2006

IZA
P.O. Box 7240
53072 Bonn
Germany

Phone: +49-228-3894-0

Fax: +49-228-3894-180

Email: iza@iza.org

\begin{abstract}
Any opinions expressed here are those of the author(s) and not those of the institute. Research disseminated by IZA may include views on policy, but the institute itself takes no institutional policy positions.

The Institute for the Study of Labor (IZA) in Bonn is a local and virtual international research center and a place of communication between science, politics and business. IZA is an independent nonprofit company supported by Deutsche Post World Net. The center is associated with the University of Bonn and offers a stimulating research environment through its research networks, research support, and visitors and doctoral programs. IZA engages in (i) original and internationally competitive research in all fields of labor economics, (ii) development of policy concepts, and (iii) dissemination of research results and concepts to the interested public.
\end{abstract}

IZA Discussion Papers often represent preliminary work and are circulated to encourage discussion. Citation of such a paper should account for its provisional character. A revised version may be available directly from the author. 
IZA Discussion Paper No. 2265

August 2006

\section{ABSTRACT}

\section{Phillips Curves and Unemployment Dynamics: A Critique and a Holistic Perspective}

The conventional wisdom that inflation and unemployment are unrelated in the long-run implies that these phenomena can be analysed by separate branches of economics. The macro literature tries to explain inflation dynamics and estimates the NAIRU. The labour macro literature tries to explain unemployment dynamics and determine the real economic factors that drive the natural rate of unemployment. We show that the orthodox view that the New Keynesian Phillips curve is vertical in the long-run and that it cannot generate substantial inflation persistence relies on the implausible assumption of a zero interest rate. In the light of these results, we argue that a holistic framework is needed to jointly explain the evolution of inflation and unemployment.

JEL Classification: E24, E31

Keywords: natural rate of unemployment, NAIRU, New Keynesian Phillips Curve, inflation-unemployment tradeoff, inflation dynamics, unemployment dynamics

Corresponding author:

Marika Karanassou

Department of Economics

Queen Mary, University of London

Mile End Road

London E1 4NS

United Kingdom

E-mail: M.Karanassou@qmul.ac.uk

\footnotetext{
* Hector Sala is grateful to the Spanish Ministry of Education for financial support through grant SEC2003-7928.
} 


\section{Introduction}

In this paper we are concerned with two main categories of dynamic macro models. Phillips curve (PC) models that aim to explain inflation dynamics and models that seek to explain the evolution of the unemployment rate. Both types of models are intricately related with the natural rate of unemployment (NRU) hypothesis. The NRU is a reflection of the classical dichotomy, hence it implies that the phenomena of inflation and unemployment can be analysed by separate models. The macro literature tries to explain inflation dynamics. The labour macro literature tries to identify the determinants of the unemployment rate.

We argue that a long-run inflation-unemployment tradeoff exists, and thus we propose a holistic approach that can both model inflation dynamics and identify the driving forces of unemployment.

Inflation dynamics models treat the NRU as "exogenous" in the sense that the models do not identify the factors underlying its changes. Mainstream PC models estimate the NRU as the unemployment rate compatible with inflation stability - this is commonly referred to as the non accelerating inflation rate of unemployment (NAIRU) - and focus on the inflation-unemployment tradeoff.

On the other hand, unemployment rate models endogenise the NRU and determine the economic factors which influence it. These "endogenous" NRU models can be used to explain the long-run changes in equilibrium unemployment by identifying the business cycle and trend components of the model. ${ }^{1}$

In the context of economic models with frictions (e.g. wage/price staggering, informational stickiness, real rigidities, etc.), it is convenient to distinguish between two versions of the NRU hypothesis: In the strong-form $N R U$ monetary policy has no effect on the equilibrium unemployment rate in both the short- and long-run, whereas in the weak-form NRU monetary changes have temporary (short-run) effects on unemployment but no long-run effects. In other words, the weak-form NRU states that the equilibrium unemployment rate is independent of monetary variables only in the long-run.

The conventional wisdom is that the weak-form NRU hypothesis holds in inflation dynamics models such as the Expectations Augmented Phillips Curve (EAPC) - and its subsequent developments (triangle model of inflation, TV-NAIRU) - and the New Keynesian Phillips Curve (NPC) ${ }^{2}$. The belief in the classical dichotomy implies the existence of a vertical long-run Phillips curve whose intersection with the horizontal axis gives the NRU.

\footnotetext{
${ }^{1}$ Tobin (1998) argues that the NAIRU and NRU are not synonymous. However, such a distinction becomes superfluous within our framework of "exogenous/endogenous" NRU models.

${ }^{2}$ For the etymology of the term "New Keynesian", see Gordon (1990). It is often also called the "New Phillips curve" or the "New Neoclassical Synthesis." Helpful surveys include Clarida, Gali and Gertler (1999), Gali (2003), Mankiw (2001), Roberts (1995) and Goodfriend and King (1997).
} 
Unemployment models analyse the structure of the labour market through traditional dynamics (i.e. single unemployment rate equations) or interactive dynamics (i.e. multi-equation systems with spillover effects). There is an important disparity between the two approaches regarding the NRU hypothesis. It can be shown that in interactive dynamics models, as opposed to single unemployment rate dynamic equations, the $\mathrm{NRU}$ is misleading as a reference point for the long-run movements of the equilibrium unemployment rate when the exogenous variables have constant but nonzero long-run growth rates.

Furthermore, recent models of the NPC show that a downward sloping PC does exist and money is not super-neutral. We call these models the Frictional Growth New Keynesian Phillips Curve (FG-NPC) and their contribution is to demonstrate that even the slightest asymmetry in the backward- and forward-looking elements of price behaviour can generate a significant long-run tradeoff between real and nominal variables. This asymmetry arises because of time discounting and a nonzero interest rate. In other words, whereas the standard NPC is consistent with the weak-form NRU hypothesis, the FG-NPC refutes it. ${ }^{3}$

Table 1 summarises the above classification of inflation/unemployment models. As pointed out, these are commonly considered as separate branches of study.

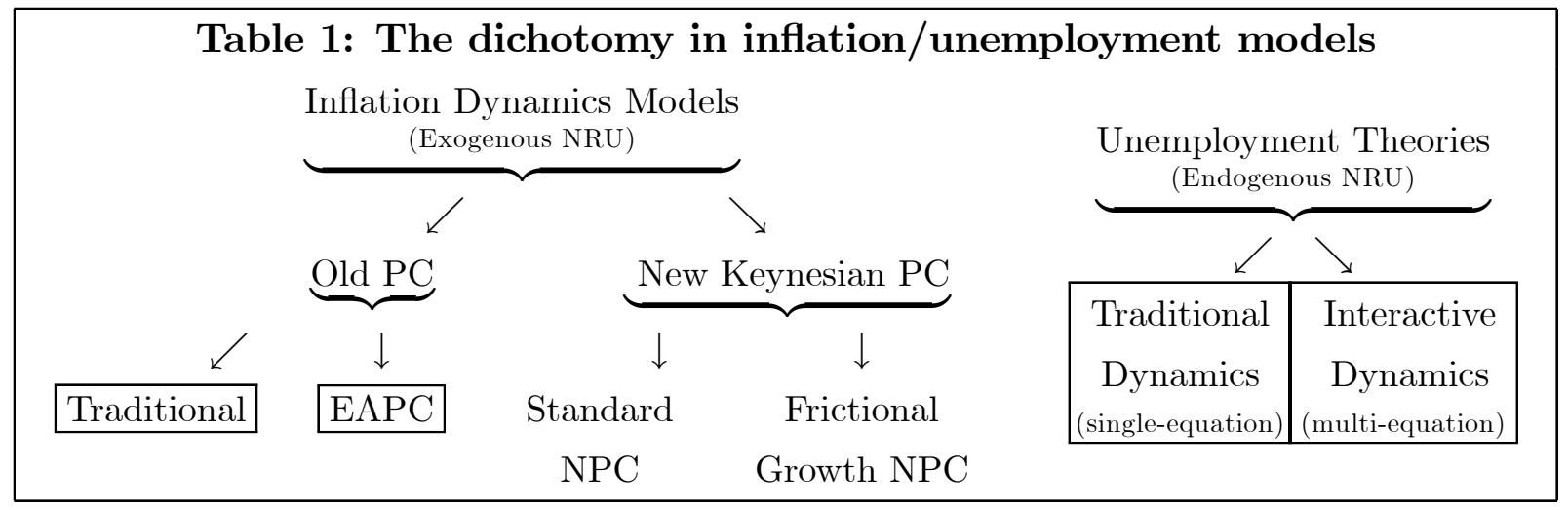

From the empirical side, a number of recent papers have also started to question the dichotomy between the real and nominal sides of the economy, and consider the possibility of long-lasting effects derived from changes in the monetary policy. For example, Fisher and Seater (1993), King and Watson (1994) and Fair (2000) find a longrun inflation-unemployment tradeoff; Campbell and Mankiw (1987) find long-lasting real GDP responses to monetary disturbances in the US; along the same lines, the real GDP impulse response function (IRF hereafter) estimated by Bernanke and Mihov (1998) does not converge to zero (albeit the standard errors increase enough to include the zero line); Ball (1997 and 1999) studies the OECD countries and relates long disinflationary periods with increases in their NRUs; Dolado, López-Salido and Vega (2000) provide scenarios of

\footnotetext{
${ }^{3}$ Karanassou and Snower (2004) show that the standard formulation of the NPC is simply a highly implausible restricted case of price/wage staggering.
} 
nonvertical long-run Phillips curve slopes for Spain; Akerlof, Dickens, and Perry (1996 and 2000) claim that at low inflation levels departures from fully rational decisions generate inflation-unemployment long-run tradeoffs; more recently, Karanassou, Sala and Snower (2002, 2003b and 2005) present empirical unemployment IRFs for Spain, the EU and the US which do not converge to the initial equilibrium when these economies are hit by a permanent monetary shock.

Theoretical and empirical evidence against the classical dichotomy calls for a holistic approach that takes into account the intimate dynamic relation between inflation and unemployment.

The structure of the paper is as follows. Section 2 gives the definitions of some fundamental concepts in dynamic macro models: the short-run, long-run, and steadystate equilibriums of a stochastic process. Section 3 outlines the standard Phillips curve models, as they developed over the decades and singles out the restrictions under which there is no inflation-unemployment tradeoff in the long-run. Section 4 discusses and compares the traditional and interactive dynamics theories of unemployment. Section 5 presents the theoretical underpinnings of a non-vertical Phillips curve. Section 6 proposes a holistic framework that aims to jointly analyse the inflation and unemployment phenomena. Finally, Section 7 concludes.

\section{Concepts and Definitions}

To facilitate our analysis, we first offer clear definitions of the widely used, and occasionally confused, concepts of equilibrium: short-run, steady-state, and long-run. In what follows the dependent variable $y_{t}$ refers to (the log of) a macroeconomic magnitude, e.g. unemployment rate, inflation rate, output, marginal costs, etc.

Considering a stochastic equation for the macro variable $y_{t}$, the short-run (SR) equilibrium is given by the conditional expectation of $y_{t}$ given the values of the explanatory variables, while the long-run (LR) equilibrium is the unconditional expectation of the stochastic process.

We start our exposition with the following static equation:

$$
y_{t}=\gamma x_{t}+\varepsilon_{t}
$$

where $x_{t}$ is a $k \times 1$ vector of exogenous variables, $\gamma$ is a $1 \times k$ vector of coefficients, and $\varepsilon_{t}$ is a strict white noise error term (i.e. independently, identically distributed with zero mean and constant variance). It is easy to see that the SR equilibrium of $y_{t}$ is simply

$$
E_{x} y_{t}=\gamma x_{t}
$$


where $E_{x} y_{t}$ is a short-hand notation for the conditional expectation $E\left(y_{t} \mid x_{t}\right)$, and the LR equilibrium is

$$
E\left(y_{t}\right)=\gamma E\left(x_{t}\right)
$$

where $E(\cdot)$ denotes the unconditional expectation of a random variable. Note that although the short- and long-run solutions (2)-(3) of a static model share the same slope coefficients, the short- and long-run values of $y_{t}$ depend on the evolution of the exogenous variable and thus will obviously differ.

Next, let $y_{t}$ follow a simple dynamic process: ${ }^{4}$

$$
y_{t}=\alpha y_{t-1}+\gamma x_{t}+\varepsilon_{t}
$$

where the autoregressive coefficient $\alpha$ is less than one in absolute value. Once again, the conditional expectation gives the short-run equilibrium value, $y_{t}^{S R}$ :

$$
y_{t}^{S R} \equiv E_{t-1, x} y_{t}=\alpha y_{t-1}+\gamma x_{t}
$$

where $E_{t-1, x} y_{t}$ is a short-hand notation for the conditional expectation $E\left(y_{t} \mid y_{t-1}, x_{t}\right)$.

As we explained above, the long-run equilibrium is generally obtained by the unconditional expectation of the dynamic equation. Under the assumption that the endogenous variable stabilises (i.e., it has zero growth) in the long-run, the long-run equilibrium is commonly referred to as the steady-state value of $y$. This is given by

$$
\begin{aligned}
E\left(y_{t}\right) & =\frac{\gamma}{1-\alpha} E\left(x_{t}\right), \text { or } \\
y^{s s} & =\frac{\gamma}{1-\alpha} x^{s s},
\end{aligned}
$$

where the superscript ${ }^{s s}$ denotes the value at which the variable stabilises in the long-run.

It is important to note that the NRU $\left(u^{n}\right)$ is generally perceived as synonymous to the steady-state unemployment rate, i.e. $u^{n} \equiv u^{s s}$.

In empirical work, the unknown expectation of $x_{t}$ can be replaced by its permanent component. ${ }^{5}$ In other words, the steady-state can be defined as the equilibrium unemployment rate at which there is no tendency for this rate to change at any time $t$, given the permanent component values of the exogenous variables at that time.

If instead, the endogenous variable grows at a constant rate in the long-run (due to the non-zero long-run growth rates of the exogenous variables), then the long-run

\footnotetext{
${ }^{4}$ For ease of exposition, the right-hand side of the equation includes only the first lag of $y_{t}$ and only one exogenous variable.

${ }^{5}$ The permanent component of a series is usually obtained by filtering the series using the HodrickPrescott technique.
} 
equilibrium is

$$
\begin{aligned}
E\left(y_{t}\right) & =\frac{\gamma}{1-\alpha} E\left(x_{t}\right)-\frac{\alpha}{1-\alpha} E\left(\Delta y_{t}\right), \text { or } \\
y_{t}^{L R} & =\frac{\gamma}{1-\alpha} x_{t}^{L R}-\frac{\alpha}{1-\alpha} \Delta y^{L R}, \Rightarrow \\
y_{t}^{L R} & =\frac{\gamma}{1-\alpha} x_{t}^{L R}-\frac{\alpha \gamma}{(1-\alpha)^{2}} \Delta x^{L R},
\end{aligned}
$$

where $\Delta$ denotes the difference operator, the superscript $L R$ denotes the long-run value (unconditional expectation) of the variable, and the subscript $t$ signifies the fact that the level of the variable does not stabilise in the long-run. ${ }^{6}$

Similarly to the steady-state case, in applied work the unconditional expectations of the variables are replaced by their permanent components. Therefore, the long-run represents the equilibrium unemployment rate at which there is no tendency for this rate to change at any time $t$, given the permanent component values of the exogenous variables and their growth rates at that time.

Observe that the steady-state (6) and long-run (7) solutions of the stochastic equation (4) have identical slope (elasticity) coefficients with respect to the exogenous variable.

For analytical purposes, it is of interest to distinguish three cases regarding the time series properties of the variables: ${ }^{7}$ (i) The variables are stationary, i.e. their level stabilises in the long-run, and thus the steady-state solution (6) can adequately describe the long-run equilibrium. (ii) The stochastic equation (4) represents a stationary linear combination of $\mathrm{I}(1)$ variables without drift. In this case $x_{t}$ does not grow and so the long-run value of $y$ should be derived by setting $\Delta x^{L R}=0$ in eq. (7). In this case, a shock has a permanent effect and thus the long-run values depend on the period $t$ shock. $^{8}$ (iii) When the growth rate of the variables stabilises in the long-run, i.e. the variables are either trend stationary or I(1) with drift, the long-run solution (7) should

${ }^{6}$ To derive the long-run solution it is convenient to rewrite the dynamic equation (4) as follows:

$$
y_{t}=\frac{\gamma}{1-\alpha} x_{t}-\frac{\alpha}{1-\alpha} \Delta y_{t}+\frac{1}{1-\alpha} \varepsilon_{t}
$$

We thank Ron Smith for suggesting this handy way to rewrite an autoregressive equation.

We then apply the expectations operator on both sides of the above parameterisation to get eq. (7):

$$
E\left(y_{t}\right)=\frac{\gamma}{1-\alpha} E\left(x_{t}\right)-\frac{\alpha}{1-\alpha} E\left(\Delta y_{t}\right) .
$$

Instead of explicitly solving for the unconditional expectation of the dynamic equation (4), it is standard to obtain the steady-state solution mechanically: discard the error term, set lagged values equal to current ones and solve for the dependent variable. Note, however, that this mechanical procedure does not take into account a non zero long-run growth rate.

${ }^{7}$ Although $\mathrm{I}(2)$ or fractionally integrated stochastic processes do exist and are of great interest, I(1) and stationary processes dominate in the models in the macro/labour literature that we examine.

${ }^{8}$ To see this, let the exogenous variable $x_{t}$ follow a random walk without drift: $x_{t}=x_{t-1}+\varepsilon_{t}$, 
be derived.

Since the steady-state (6) and long-run (7) solutions have the same elasticities, and economics mainly focuses on elasticities, it is common practice in the literature to use these concepts interchangeably. However, as shown above, this can be a very misleading practice if we are interested in the long-run value of the process and the exogenous variables have constant but nonzero long-run growth rates.

In the light of the above definitions, we analyse the Phillips curve ("exogenous" NRU) models and, in turn, the unemployment dynamics ("endogenous" NRU) models.

\section{Macro Building Blocks: The Phillips Curve}

\subsection{The Traditional Phillips Curve}

There are some simple models in which the short- and long-run tradeoffs coincide. The simplest example is the traditional Phillips curve. This was born as an empirical regularity documented first by Phillips in 1958 for the UK, and by Samuelson and Solow in 1960 for the US. ${ }^{9}$ The original formulation is given by

$$
\pi_{t}=c-b u_{t}+\varepsilon_{t}
$$

where $\pi_{t}$ is the inflation rate, $u_{t}$ is the unemployment rate, $b$ and $c$ are positive constants. Given the static nature of the equation, the steady-state and long-run unemployment rates are identical. Note that in equilibrium the error term becomes zero and the above PC becomes $\pi_{t}=c-b u_{t}$. Therefore, the short- and long-run inflation-unemployment tradeoffs coincide and are equal to $-b$. The existence of a non-zero long-run tradeoff implies a non-vertical PC and thus no NRU/NAIRU exists.

An immediate dynamic extension of (8) is the so-called traditional Keynesian Phillips

so that $x_{t+k}=x_{t}+\sum_{j=1}^{k} \varepsilon_{t+j}$. It is clear that the expectation of the process depends on its current value $x_{t}$. In other words, the long-run value of an $\mathrm{I}(1)$ process is effectively given by its expectation conditional on the period $t$ value of the exogenous variable $x$. Thus, the use of both a superscript $L R$ and a subscript $t$ in our notation $\left(x_{t}^{L R}\right)$ merely signifies the fact that the permanent change in the exogenous variable drives its long-run relation with the dependent variable. Had $x_{t}$ been stationary, it would have, with the passage of time, reverted to its equilibrium value, say $x^{L R}$, regardless of the value $x_{t}$ where the shock pushed it at period $t$. For example, if at period $t$ the exogenous variable is shocked from an equilibrium of $3 \%$ to a value $x_{t}=6 \%$, it will revert back to its pre-shock equilibrium in the long-run: $x^{L R}=3 \%$. On the other hand, the random walk property of the process forces it to stay forever at the value it acquires at period $t, x_{t}$. Thus, we denote this long-run value of $6 \%$ by $x_{t}^{L R}$ to distinguish it from the mean reverting case.

${ }^{9}$ Tobin (1998, p. 3) states that "Irving Fisher (1926) anticipated Phillips...(His article was) scarcely noticed, while Phillips's article came at a time when the subject was at the forefront of professional and political attention." 
curve:

$$
\pi_{t}=c+a \pi_{t-1}-b u_{t}+\varepsilon_{t}
$$

where the autoregressive parameter is $|a|<1$. As explained in the previous section, due to the dynamic nature of (9), the short- and long-run tradeoffs are $-b$ and $\frac{-b}{1-a}$, respectively. Similarly to the static case, there is a long-run tradeoff and no NRU.

Following the analysis in section 2, the long-run solution of the above dynamic model is

$$
\pi^{L R}=\frac{c}{(1-a)}-\frac{b}{(1-a)} u^{L R}-\frac{a}{(1-a)} \Delta \pi^{L R}
$$

Assuming that inflation stabilises in the long-run, i.e. $\Delta \pi^{L R}=0$, the long-run unemployment rate reduces to the steady-state one:

$$
u^{L R} \equiv u^{s s}=-\frac{1-a}{b} \pi^{L R}+\frac{c}{b}
$$

Note that $\frac{c}{b}$ gives the unemployment rate at which prices are stabilised.

\subsection{The Expectations Augmented Phillips Curve}

At the end of the 60s, the seminal contributions by Phelps and Friedman on the NRU hypothesis gave rise to the expectations-augmented Phillips curve (EAPC): ${ }^{10}$

$$
\pi_{t}=\pi_{t}^{e}-b\left(u_{t}-u^{n}\right)
$$

where $\pi^{e}$ denotes expected inflation and $u^{n}$ is the NRU/NAIRU.

To solve for expected inflation we need to assume a stochastic process governing inflation, and/or a model for expectations.

Since the models that follow have been widely used in the literature, and given that our main focus is to point out the restrictions under which they lead to a vertical PC in the long-run, we will abstain from any microfoundations considerations.

\subsubsection{The Random Walk/Rational Expectations Model}

It has been commonplace in the literature to assume that (i) inflation follows a random walk without drift

$$
\pi_{t}=\pi_{t-1}+\varepsilon_{t}
$$

and (ii) expectations are rational:

$$
\pi_{t}^{e} \equiv E_{t-1} \pi_{t}
$$

\footnotetext{
${ }^{10}$ Fuhrer (1997) calls this equation the expectations-augmented price-price Phillips curve.
} 
where $E_{t-1}$ is the expectations operator conditional on information available at $t-1$.

The random walk hypothesis implies that the best prediction of current inflation is past inflation

$$
E_{t-1} \pi_{t}=\pi_{t-1}
$$

Substituting (13) in (11) gives

$$
\pi_{t}=\pi_{t-1}-b\left(u_{t}-u^{n}\right)
$$

Thus the NAIRU $u^{n}$ is the unemployment rate at which inflation is stabilised in the long-run. ${ }^{11}$ It is easy to see that the above PC is vertical (zero tradeoff) in the long-run, while the short-run inflation-unemployment tradeoff is $-b .{ }^{12}$

\subsubsection{The Adaptive Expectations Model}

The rational and adaptive expectations models are compatible. Under adaptive expectations, expected inflation is a linear combination of last period's expected inflation and last period's prediction error:

$$
\begin{aligned}
\pi_{t}^{e} & =\pi_{t-1}^{e}+\phi\left(\pi_{t-1}-\pi_{t-1}^{e}\right) \\
& =(1-\phi) \pi_{t-1}^{e}+\phi \pi_{t-1}
\end{aligned}
$$

where $0<\phi<1$ is the degree of correction. ${ }^{13}$

Let us rewrite equation (15) as

$$
[1-(1-\phi) B] \pi_{t}^{e}=\phi \pi_{t-1}
$$

where $B$ is the backshift operator. This means that agents determine their expectation of current inflation as a weighted average of past inflation rates. Substitute (16) into (11) to obtain

$$
\pi_{t}=\pi_{t-1}-b\left(u_{t}-u^{n}\right) .
$$

\footnotetext{
${ }^{11}$ According to Tobin $(1998$, p. 7$)$ the NAIRU concept originated in Modigliani and Papademos (1976).

${ }^{12}$ The above model is consistent with the NAIRU model proposed by Layard, Nickell, and Jackman (1991). Its simple standard version contains a wage setting curve, where nominal wages are fixed as a mark-up over expected prices, and a price setting curve where prices are a fixed mark-up over expected wages. Assuming that price and wage shocks are of equal magnitude, and inflation follows a random walk without drift, the intersection of the price and wage curves yields the EAPC (14). Thus, it can be shown that the inflation-unemployment tradeoff, $-b$, is a linear function of the sensitivity of price and wage setting to the unemployment rate.

${ }^{13}$ When $\phi=1$, the adjustment device becomes extrapolative expectations: $\pi_{t}^{e}=\pi_{t-1}$. In this case, agents think the best prediction of inflation in period $t$ is the actual value of inflation in $t-1$. When $\phi=0$, the adjustment device becomes constant expectations $\pi_{t}^{e}=\pi_{t-1}^{e}$. In this case agents are stubborn, ignore their past mistakes in predicting current inflation, and choose the past inflation prediction as the best prediction in $t$.
} 
Therefore, the EAPC under adaptive expectations is identical to the EAPC under the random walk/rational expectations assumption (14).

\subsubsection{The Autoregressive/Rational Expectations Model}

Next, assume that inflation follows a stationary $\mathrm{AR}(1)$ process instead of a random walk: ${ }^{14}$

$$
\pi_{t}=a \pi_{t-1}+\varepsilon_{t}
$$

where the autoregressive coefficient $a$ lies inside the unit circle. ${ }^{15}$ Using rational expectations (12), the best prediction for next period's inflation is

$$
E_{t-1} \pi_{t}=a \pi_{t-1}
$$

Substituting (18) in (11) gives the EAPC under the AR(1)/rational expectations assumption:

$$
\pi_{t}=a \pi_{t-1}-b\left(u_{t}-u^{n}\right)
$$

Similarly to the EAPC under the random walk/rational expectations assumption (14), the short-run inflation-unemployment tradeoff implied by (19) is $-b$. However, under the $\mathrm{AR}(1)$ assumption, there is a long-run tradeoff $\left(\frac{-b}{1-a}\right)$ and a downward sloping long-run PC. In other words, $u^{n}$ cannot be interpreted as the NRU/NAIRU; it is simply a component of the vertical axis intercept of the PC.

Note that if $a$ is restricted to be unity, the above Phillips curve reduces to the EAPC under the random walk/rational expectations assumption (14).

\subsubsection{The Triangle Model of Inflation}

According to Gordon (1983, 1997a, 1998), the lack of supply shocks in the EAPC creates a problem of omitted variables which biases the coefficient of unemployment towards zero. The need to consider supply shocks leads to the triangle model of inflation:

$$
\pi_{t}=\pi_{t-1}-b\left(u_{t}-u^{n}\right)+d z_{t},
$$

\footnotetext{
${ }^{14}$ The time series properties of inflation are a hotly debated and unresolved issue. See footnote 19 for studies that show that inflation follows a stationary process.

${ }^{15}$ For expositional simplicity we assume a first-order autoregressive process instead of a higher order stationary AR model:

$$
\pi_{t}=a(B) \pi_{t-1}+\varepsilon_{t},
$$

where the roots of the polynomial $[1-a(B)]=0$ lie outside the unit circle.
} 
where lagged inflation captures the degree of nominal sluggishness, $z_{t}$ is a $k \times 1$ vector of supply shocks (e.g. productivity shocks), and $d$ is a $1 \times k$ vector of parameters. ${ }^{16}$ The "triangle" refers to the three factors that influence inflation: lags, demand, and supply.

The unemployment gap $\left(u_{t}-u^{n}\right)$ is a measure of excess demand which can alternatively be proxied by: (i) the output gap, defined as the percentage deviation of actual output with respect to potential output, ${ }^{17}$ and (ii) the capacity utilization gap, defined as the difference between the degree of capacity utilization and its non accelerating inflation rate (NAIRCU).

Observe that in (20) expectations are not explicitly considered since price inertia is compatible with both rational and adaptive expectations. In this setting, the divergence between the actual and the steady-state unemployment rate arises from unexpected inflation and the supply-side shocks. Note that, although no assumption about expectations is made, the triangle model (20) assumes that inflation follows a random walk.

Furthermore, it is easy to see that, like the previous standard versions of the EAPC model, the Phillips curve is downward sloping in the short-run, vertical in the long-run, and the NRU/NAIRU is equal to $u^{n} .^{18}$

When the autoregressive coefficient in $(20)$ is not restricted to unity $(a \neq 1)$, the triangle model is given by

$$
\pi_{t}=a \pi_{t-1}-b\left(u_{t}-u^{n}\right)+d z_{t}
$$

For analytical purposes it is important to distinguish the following three cases arising from the time series properties of the variables in the above (unrestricted) triangle model (21):

1. If inflation is $\mathrm{I}(1)$, and excess demand and supply shocks are $\mathrm{I}(0)$, a balanced equation can be obtained only if the restriction $a=1$ is imposed. This is the case of the conventional triangle model (20).

2. Inflation is $\mathrm{I}(1)$, excess demand and supply shocks are also $\mathrm{I}(1)$, and all variables cointegrate. In this case the triangle model is dynamically stable, i.e. $|a|<1$, and thus no NRU/NAIRU exists.

\footnotetext{
${ }^{16}$ For expositional ease, we use the above simple $\operatorname{ARDL}(1,0,0)$ instead of the general model

$$
\pi_{t}=a(B) \pi_{t-1}+b(B) x_{t}+d(B) z_{t}
$$

where $a(1)=1$. That is, one root of the polynomial equation $[1-a(B)]=0$ is unity while the rest lie ouside the unit circle. This means that inflation follows an $\mathrm{I}(1)$ process. Also, without loss of generality, we ignore the error term.

${ }^{17}$ Okun's law links the unemployment and output gaps. Its simplest expression is $\left(u_{t}-u^{n}\right)=$ $-\theta\left(y_{t}-y^{n}\right)$, where $y$ is the log of real output and $y^{n}$ its natural level.

${ }^{18}$ This is because of the absence of shocks in the steady-state.
} 
3. Inflation is $I(0)$, and excess demand and supply shocks are also $I(0)$. Thus the model is stationary $(|a|<1)$ and, similarly to the previous case, no NRU/NAIRU exists.

The above demonstrates that the vertical long-run PC relies heavily on the assumption that inflation is nonstationary. ${ }^{19}$

\subsubsection{The Time-Varying NAIRU (TV-NAIRU)}

The NRU/NAIRU is understood as the unemployment rate needed to stabilise inflation, given the "nature" of the economy. One popular extension of the triangle model is the time-varying NRU/NAIRU (TV-NAIRU) which allows the "nature" of the economy to change over time. ${ }^{20}$

The TV-NAIRU assumes that the natural rate of unemployment in equation (20) follows a random walk:

$$
\begin{aligned}
\pi_{t} & =\pi_{t-1}-b\left(u_{t}-u_{t}^{n}\right)+d z_{t} \\
u_{t}^{n} & =u_{t-1}^{n}+\varepsilon_{t}
\end{aligned}
$$

where $\varepsilon_{t} \sim i i d\left(0, \sigma^{2}\right)$. When $\sigma^{2}$ is positive, the NRU/NAIRU varies, whereas when $\sigma^{2}$ is zero, the NRU/NAIRU is constant. ${ }^{21}$

Observe that the auxiliary equation (23) in the TV-NAIRU model is consistent with the hysteresis theory for unemployment: any shock can have a permanent effect on the long-run equilibrium rate, i.e. the NRU/NAIRU. It is an atheoretical time series perspective of the NRU/NAIRU, and thus cannot identify the economic factors that account for its dynamic evolution.

\subsection{The New Phillips Curve (NPC)}

The staggered wage contracts proposed by Taylor $(1979,1980 \mathrm{a})$ paved the way for the new Phillips curve by accommodating monetarist and rational expectations elements in the wage-price setting. ${ }^{22}$

The main alternative models of time-contingent nominal contracts are (i) the Rotemberg (1982) model (in which each firm is assumed to face quadratic costs of price adjust-

\footnotetext{
${ }^{19}$ This is a contestable assumption. There is a substantial literature on the relation between inflation and inflation uncertainty that estimates stationary inflation ARMA-GARCH models (see, for example, Grier and Perry, 1998). Also, Bullard and Keating (1995) show that inflation is stationary in thirty-one countries. Furthermore, Ahmed and Rogers (2000) point out that "the unit root in inflation is small compared to the unit roots in the productivity and fiscal trends." (p. 25).

${ }^{20}$ The TV-NAIRU was proposed by Gordon (1997) and Staiger, Stock and Watson (1997a and 1997b).

${ }^{21}$ Gordon (1997) chooses $\sigma^{2}=0.2$ to limit the variation of the NRU/NAIRU.

${ }^{22}$ The wage-staggering model is also attributed to Phelps (1978).
} 
ment, which it minimises) and (ii) the particularly popular Calvo (1983) model (in which each firm has to keep its price fixed until it receives a random "permission-to-adjustprice" signal, and the probability of receiving this signal remains constant through time). These alternatives however are problematic.

In Rotemberg's approach, it is unclear why the cost of price change should be positively related to the magnitude of price change. In fact, the menu cost literature has been built up on the explicit assumption that no such relation exists. Regarding Calvo's approach, it is obviously far-fetched to assume that a firm's probability of price adjustment is independent of how long it has been since its last price adjustment.

Nevertheless, the Calvo model is commonly used as a convenient algebraic shorthand for the Taylor model. ${ }^{23}$ Goodfriend and King (1997, p.254) show that under intertemporal optimisation and certain conditions, ${ }^{24}$ Calvo's setup broadly resembles that of Taylor.

Below we first summarise Taylor's wage-staggering model and then present and evaluate the standard sticky-price model of the NPC literature.

\subsubsection{Wage-Staggering Contracts}

The seminal contribution of Taylor's work is that it gives an economic justification to unemployment rate dynamics. It thus strengthens the case against the view that the autoregressive nature of the unemployment rate is merely a statistical one - if one could observe and include in the model all the relevant exogenous variables, lagged unemployment terms would simply become statistically insignificant. Taylor used a standard macro model with rational expectations and showed that wage staggering alone induces unemployment to depend on its own lags.

In its simplest form, wage staggering assumes that nominal wages are fixed for two periods and there are two contracts that are evenly staggered. The Taylor equation postulates that the contract wage depends on past and expected future contract wages, as well as current and future excess labour demand:

$$
W_{t}=\alpha W_{t-1}+(1-\alpha) E_{t} W_{t+1}+\gamma\left[\alpha x_{t}+(1-\alpha) E_{t} x_{t+1}\right]+\omega_{t},
$$

where the contract wage $W_{t}$ is set at the beginning of period $t$ for periods $t$ and $t+1$, $x_{t}$ denotes excess demand, $E_{t}(\cdot)$ is the expectation of the variable conditional upon information available at time $t$, and the supply shock $\omega_{t}$ is a white noise process. (All variables are in logs.) The demand sensitivity parameter $\gamma$ describes how strongly wages

\footnotetext{
${ }^{23}$ Also, as Goodfriend and King (1997) point out (p. 249), New Keynesian economists who felt uneasy about wage-staggering contracts found Calvo's price-setting model quite attractive.

${ }^{24}$ These conditions are low inflation, constant elasticity of demand, and small variations in adjustment patterns.
} 
are influenced by demand. Note that the only restriction that needs to be imposed on the backward- and forward-looking weights is that they add up to unity - they do not have to be equal to one another. ${ }^{25}$

Assuming constant returns to labour in the production function, the (log) price level is a constant markup over the average wage: $P_{t}=\frac{1}{2}\left(W_{t}+W_{t-1}\right)$. Taylor (1980a, p.4-5) closed his macro model by assuming that excess labour demand is proportional to the output gap and output gap depends on detrended real money balances. The supply and demand sides of the economy are equilibrated through the wage contract equation (24). Taylor (1980a) shows that the rational expectations solution of the above two-period contract wage model yields an $\operatorname{ARMA}(1,1)$ equation for the unemployment rate.

\subsubsection{The Sticky-Price Model of the NPC}

Taylor's and Calvo's wage/price-setting models were subsequently reformulated into what has become known as the workhorse model of the New (Keynesian) Phillips Curve. ${ }^{26}$

The NPC explains current inflation $\pi_{t}$ by expected inflation one period ahead and a forcing variable $x_{t}$ :

$$
\pi_{t}=\beta E_{t} \pi_{t+1}+\gamma(1+\beta) x_{t},
$$

where $x_{t}$ denotes excess demand or marginal costs (i.e., unemployment rate, (log) output gap, or (log) wage share), $\gamma$ is the "demand sensitivity parameter" (a constant), and inflation is the first difference of the log price level, $\pi_{t} \equiv P_{t}-P_{t-1}$. In contrast to the "old" PC, the NPC is forward-looking and past inflation rates only matter if they are correlated with the rational expectation of next period's inflation rate.

The New Phillips curve (25) is simply a reparameterisation of the following pricesetting equation: ${ }^{27}$

$$
P_{t}=\alpha P_{t-1}+(1-\alpha) E_{t} P_{t+1}+\gamma x_{t}
$$

where the discount parameter $\alpha=\frac{1}{1+\beta}$ (the discount factor $\beta=\frac{1}{1+r}$, and $r$ is the discount rate). ${ }^{28}$ The lagged price term captures nominal rigidities and so equation (26) clearly implies price inertia: a demand shock affects the price level for many periods.

Throughout the past decade, the New Phillips curve (25) has been receiving a lot of theoretical and empirical support. ${ }^{29}$ It is certainly true to say that the conventional

\footnotetext{
${ }^{25}$ However, the wage-staggering specification in Taylor (1980a) attaches equal weights to the backward- and forward-looking variables.

${ }^{26}$ See, for example, Roberts (1995), Gali and Gertler (1999), and Mankiw and Reis (2002).

${ }^{27}$ To obtain the New Keynesian Phillips curve (25), subtract from both sides of the price-setting eq. (26) (i) $P_{t-1}$ to get $\pi_{t}-(1-\alpha) P_{t-1}=(1-\alpha) E_{t} P_{t+1}+\gamma x_{t}$, and (ii) $(1-\alpha) P_{t}$ so that $\alpha \pi_{t}=$ $(1-\alpha) E_{t} \pi_{t+1}+\gamma x_{t}$.

${ }^{28}$ We discuss this result in detail in Section 5 .

${ }^{29}$ See Gali and Gertler (1999), Svensson (2000), Gali, Gertler, and Lopez-Salido (2001), and the
} 
analyses of the NPC are broadly compatible with the NAIRU: When the interest rate is zero (so that $\alpha=1 / 2$ and $\beta=1$ ), equation (25) reduces to the standard textbook version of the Phillips curve, for which there is no long-run tradeoff between inflation and unemployment/output. Since $\beta \approx 1$, it is generally taken for granted that the longrun Phillips curve is almost vertical. As we will show in Section 5, the long-run slope is a function of both $\beta$ and $\gamma$ and it is highly sensitive to the value of $\gamma$.

The choice of the forcing variable is crucial when estimating the inflation dynamics associated with the Phillips curve. Galí and Gertler (1999), Galí, Gertler and LópezSalido (2001) estimate (25) with GMM and find evidence in support of the NPC only when they use labour income share (rather than the output gap or unemployment) as the forcing variable. As Galí and Gertler indicate, the resulting equation can be called an inflation dynamics equation, rather than a Phillips curve, since the latter is meant to describe the relation between inflation and some measure of the magnitude of macroeconomic activity. It is important to note that the labour income share is essentially the wage-productivity gap. ${ }^{30}$ Thus the positive and significant relation between inflation and labour share evidenced in the above papers, is simply a reflection of the downward pressure put on inflation when wage gains trail productivity gains.

The "Forcing" Variable The use of term "forcing" variable in the single-equation standard and hybrid NPC models suggests the exogeneity of $x_{t}$. (The hybrid NPC is given below.) But in the context of all reasonable macro models of the Phillips curve, $x_{t}$ is not exogenous. Rather, inflation $\pi_{t}$ and the real variable $x_{t}$ are both endogenous responding to economic policy changes. In Section 5 we show that the endogeneity of the "forcing" variable has important implications for both the persistence of inflation and the slope of the PC in the long-run.

Karanassou, Sala, and Snower $(2002,2005)$ examine, theoretically and empirically, the inflation-unemployment tradeoff in the context of multi-equation systems containing both the Phillips curve as well as the relation between the real variable and the policy shock. Bårdsen, Jansen and Nymoen $(2002,2004)$ put forward an econometric evaluation of the standard and hybrid NPC's and emphasize the importance of modelling a system that includes the forcing variable as well as the rate of inflation.

special issue on the NPC of the Journal of Monetary Economics (2005).

${ }^{30}$ The labour share can be written as

$$
\frac{\text { wages }}{\text { GDP }}=\frac{\text { wages } / \text { employees }}{\text { GDP } / \text { employees }}=\frac{\text { wage }}{\text { productivity }} \text {. }
$$

So the labour share is equivalent to the ratio of average real wage and productivity. If, say, a $10 \%$ productivity gain is accompanied by a $10 \%$ growth in the average real wage, then the wage productivity gap is zero. On the other hand, the lower the wage growth, the more wages trail productivity gains and thus the higher is the wage-productivity gap. We should also note that in the literature the labour income share is used as a proxy for real marginal costs. 
Inflation Persistence and the "Forcing" Variable A major criticism against staggered nominal contacts is that, although they generate price inertia, they cannot account for the stylised fact of inflation persistence. In their influential paper, Fuhrer and Moore (1995) state that "All of the persistence in inflation derives from the persistence in the driving term..." (p. 129). Using recursive substitution, eq. (25) can be expressed as

$$
\pi_{t}=\gamma(1+\beta) \sum_{j=0}^{\infty} \beta^{j} E_{t} x_{t+j}
$$

Thus a one-off change in the driving force variable in period $t$ cannot affect inflation beyond that period. ${ }^{31}$

The so called hybrid NPC deals with this deficiency by adding lagged inflation terms to the standard PC:

$$
\pi_{t}=\beta^{b} \pi_{t-1}+\beta^{f} E_{t} \pi_{t+1}+\gamma x_{t}
$$

In the context of the above hybrid specification of the Phillips curve, much of the current literature is concerned with the question of whether the observed inflation autocorrelation results from backward-looking behaviour $\left(\beta^{f}=0\right)$ or forward-looking behaviour $\left(\beta^{b}=0\right)$ that is proxied by inflation lags. ${ }^{32}$ If the backward-looking parameter is statistically insignificant, i.e. $\beta^{b}=0$, the NPC (25) is a superior framework to the old Phillips curve.

Like the old PC, the hybrid NPC is a model that lacks solid economic foundations - empirical regularities gave rise to the old PC, while the hybrid NPC was born out of an empirical necessity.

It is important to note that the critique against the NPC for not generating inflation persistence simply relied on eye inspection of eq. (27). Subsequent studies (see for example Mankiw and Reis, 2002) analysed inflation persistence by first specifying an equation for the "forcing" variable and then deriving the closed-form rational expectations solution of the model. Commonly, the "forcing" variable depends, among other things, on real money balances and so shocks refer to money growth changes. The closed-form solutions of the standard NPC models show that

1. a temporary shock generates inflation persistence (i.e. the effects of a one-period shock on inflation gradually die out with the passage of time), and

2. a permanent shock causes inflation to adjust instantly to its new equilibrium.

\footnotetext{
${ }^{31}$ Fuhrer and Moore (1995) argue that although the Taylor model can account for slow adjustment of wages and prices, inflation is a jump variable that can adjust instantly (much like the capital stock adjusts slowly even though investment can adjust instantly).

${ }^{32}$ See, for example, Galí and Gertler (1999), Bårdsen, Jansen and Nymoen (2002, 2004), and Rudd and Whelan (2005).
} 
Therefore, a widely recognised deficiency of the NPC is that it implies that inflation is a jump variable - following a permanent increase (decrease) in money growth at period $t$, inflation jumps up (down) instantaneously to its new long-run value.

This is exactly what is meant by the, somehow confusing, statement that "the NPC does not generate inflation persistence". It was precisely because of this perceived deficiency of the NPC (or sticky-price Phillips curve) that Mankiw and Reis (2002) proposed the sticky-information PC which can generate sufficient inflation persistence. It is also because of this inability of the standard NPC that Blanchard and Gali (2005) propose a PC model that incorporates real wage rigidities. As they put it, p. 4, "the introduction of real wage rigidities overcomes a well known empirical weakness of the standard NK model...namely, its lack of inflation inertia - which we define as the degree of inflation persistence beyond that inherited from the output gap itself."

\section{Labour Economics Building Blocks: Endogenous NRU Approaches and Unemployment Dynamics}

The endogenous NRU approaches seek to explain movements in the long-run equilibrium (or natural rate) of unemployment, by distinguishing two components. First, the so called "business cycle," i.e. the high-frequency (or conjunctural) unemployment movements which are induced by the effects of temporary shocks disrupting equilibrium. Second, the so called "trend," i.e. the low-frequency (or long-run equilibrium) movements which arise from structural changes in the unemployment determinants.

The theories discussed below endogenise the natural rate (or long-run equilibrium) of unemployment and model unemployment dynamics either via a single equation, i.e. traditional dynamics, or via a labour market system, i.e. interactive dynamics. Traditional dynamics are exemplified by the structuralist theory (ST), whereas interactive dynamics are exemplified by the chain reaction theory (CRT).

\subsection{Traditional Dynamics: The Structuralist Theory (ST)}

The aim of the structuralist theory is to disclose "the nonmonetary mechanisms through which various nonmonetary forces are capable of propagating slumps and booms in the contemporary world economy." 33 Its main characteristic is the analysis of the unemployment rate via dynamic single-equation models. In this context, the NRU is the attractor of the stationary actual unemployment rate which can only temporarily deviate from its natural rate.

\footnotetext{
${ }^{33}$ Phelps (1994, p. 1)
} 
Thus, in line with conventional wisdom, the ST views the "trend" and "business cycle" components of unemployment as independent. The objective of the ST is to identify the driving forces of the "trend," i.e. the NRU. It is important to note that the ST cannot analyse the effects of permanent shocks on unemployment, since the stationary single-equation models can only feature temporary labour market shocks.

From the structuralist perspective, the trajectory of unemployment is determined by the structure of the economy, rather than by labour market lags (i.e. employment, real wage, and labour force lags). This structure is made up of two components: (i) firm's assets, which drive the labor demand; and (ii) the income from the worker's wealth, which drives the wage setting curve. Firm's assets include investments in employees, customers and tangible capital, whereas the income from worker's wealth include all returns from their private wealth - either real or financial (i.e., in the form of assets) and from their social wealth (all entitlements from the state). In recent papers, however, asset prices became the centerpiece variable of the structuralist theory. ${ }^{34}$ In other words, asset prices are the driving force determining the trajectory of the moving natural rate of unemployment.

When the ST equations include the acceleration of inflation as an explanatory variable, they are compatible with the weak-form NRU. Essentially, they can be described as augmented PC models where the time-varying NRU changes are attributed to fundamentals. ${ }^{35}$

Phelps' (1994, ch. 17) provides the estimates of a single-equation unemployment rate model for 17 OECD countries which, according to Phelps and Zoega (1998, p. 787), can be thought as a "first step in testing a moving-natural-rate theory of unemployment."

The explanatory variables in the Phelps (1994) model can be grouped in three sets: (i) unemployment lags; (ii) country-specific variables, such as total capital stock, ${ }^{36}$ real public debt, real government spending, some tax variables (direct taxes, payroll taxes), ${ }^{37}$ other institutional variables (replacement rate, duration of unemployment benefits), price markups induced by exchange rates, and some demographic/labour-supply variable (like the proportion of population between 20 and 24 years old) ${ }^{38}$; and (iii) world variables, such as the world real interest rate and the world price of oil.

The main conclusions drawn from the Phelps (1994) empirical analysis are that the

\footnotetext{
${ }^{34}$ See Phelps (1999), Fitoussi et al. (2000) and Phelps and Zoega (2001).

${ }^{35}$ See Phelps and Zoega (1998). Coakley, Fuertes and Zoega (2001) test the structuralist theory in UK, US and Germany and find support for it using a nonlinear TAR model with a one-time shift in equilibrium unemployment.

${ }^{36}$ Normalised by another variable so that its trend is removed.

${ }^{37}$ Value added taxes are not considered since they affect more or less proportionately wage and nonwage income.

${ }^{38}$ In their 1997 work, changes in the teenage share are found to be insufficiently large to explain the US unemployment movements, but the educational attainment of the different cohorts is outlined as an important factor to explain the downward trend in the natural rate.
} 
oil price was the principal determinant of the rise in unemployment in the 70 s, the real interest rates was the main driving force of unemployment in the $80 \mathrm{~s}$, and direct/payroll taxes were important in explaining the diverse experiences of the OECD countries. ${ }^{39}$

The pool of explanatory variables was augmented in subsequent works of the structuralist theorists. For example, in Phelps and Zoega (1997, 1998) three additional country-specific factors influencing the unemployment path are the slowdown of productivity (since the mid 70s), the share of social expenditures in GDP, and the educational composition of the labour force (in the US and UK).

Phelps and Zoega (1998) also examine the role played by the real exchange rate appreciation in France and Germany, resulting from their tight monetary policies, and depreciation in the periphery of the EU (Scandinavia, the Netherlands and the UK). The authors argue that exchange rate fluctuations, despite being a monetary and not a structural factor, were important for the evolution of unemployment during the 90s.

Furthermore, Phelps (1999), Fitoussi et al. (2000) and Phelps and Zoega (2001) incorporate the role of asset valuation in the analysis of the unemployment problem. Phelps (1999) concludes that asset prices help to explain employment growth in the US, and Fitoussi et al. (2000) argue that asset prices are the mechanism whereby the "New Economy" (or other developments capable of boosting firms' expected profitability, like globalization or biogenetics) enhance employment. The later study also tests three competing hypotheses for explaining the booming 90's of the OECD countries - labour market reforms, monetary theses and the "new economy" - and gives support to the "new economy" hypothesis.

Finally, for the same group of OECD countries, Phelps and Zoega (2001) argue that the long swings in economic activity result from the changes in expected future productivity which can be proxied by the swings in the stock market.

\subsection{Interactive Dynamics: The Chain Reaction Theory (CRT)}

We will show in Section 5 that the dynamics of inflation and unemployment are intimately related. This calls for a modelling procedure that can jointly determine inflation and unemployment. An interactive dynamics approach can unify the macro literature that models inflation dynamics with the labour literature that models the evolution of unemployment.

The chain reaction theory of unemployment (CRT) is an interactive dynamics approach applied to the labour market. ${ }^{40}$ To fully appreciate the value added of interactive

\footnotetext{
${ }^{39}$ In Phelps and Zoega (1998) the crucial effect of interest rates is further extended to the 90s, and the effect of taxes restricted mainly to the 60 s and 70 s.

${ }^{40}$ The CRT was developed by Karanassou and Snower (1996). See also Karanassou and Snower (1998).
} 
dynamics, we explain the workings of the CRT and then compare it with the traditional dynamics approach of the structuralist theory.

The first salient feature of the CRT is the use of dynamic multi-equation systems to analyse the trajectory of the unemployment rate. ${ }^{41}$ In the context of autoregressive multi-equation models, movements in unemployment can be viewed as "chain reactions" of responses to labour market shocks, working their way through systems of interacting lagged adjustment processes.

These lagged adjustment processes are well documented in the literature and refer, among others, to: (i) employment adjustments arising from labour turnover costs (hiring, training and firing costs), (ii) wage/price staggering, (iii) insider membership effects, (iv) long-term unemployment effects, and (v) labour force adjustments. By identifying the various lagged adjustment processes, the CRT can explore their interactions and quantify the potential complementarities/substitutabilities among them.

According to the CRT, the NRU is not a reference point for the actual unemployment rate when the long-run growth rates of the exogenous variables are nonzero constants. ${ }^{42}$ This is in stark contrast with the traditional dynamics models of the ST where the natural rate is the attractor of unemployment.

This is an important point and we illustrate it with the following simple model of labour demand and supply equations:

$$
\begin{aligned}
n_{t} & =\alpha_{1} n_{t-1}+\beta_{1} k_{t}, \\
l_{t} & =\alpha_{2} l_{t-1}+\beta_{2} z_{t},
\end{aligned}
$$

where $n_{t}$ denotes employment, $l_{t}$ is labour force, $k_{t}$ is capital stock, $z_{t}$ is working age population, the autoregressive parameters are $0<\alpha_{1}, \alpha_{2}<1$, and the $\beta$ 's are positive constants. All variables are in logs; we ignore the error terms for ease of exposition. We can plausibly assume that both capital stock and working age population are growing variables with growth rates that stabilise in the long-run. ${ }^{43}$

According to (7), the long-run solutions of the labour demand and supply equations (29)-(30) are

$$
\begin{aligned}
n_{t}^{L R} & =\frac{\beta_{1}}{1-\alpha_{1}} k_{t}^{L R}-\frac{\alpha_{1}}{\left(1-\alpha_{1}\right)} \Delta n^{L R}, \\
l_{t}^{L R} & =\frac{\beta_{2}}{1-\alpha_{2}} z_{t}^{L R}-\frac{\alpha_{2}}{\left(1-\alpha_{2}\right)} \Delta l^{L R},
\end{aligned}
$$

\footnotetext{
${ }^{41}$ Karanassou, Sala, and Snower (2004) apply the CRT to explain the evolution of the EU unemployment rate. Bande and Karanassou (2006) apply the CRT to explain regional unemployment rate disparities in Spain.

${ }^{42}$ See Karanassou and Snower (1997).

${ }^{43}$ Observe that when all variables are I(1), the labour demand and supply equations (29)-(30) imply the cointegrating vectors $\left(1,-\beta_{1} /\left(1-\alpha_{1}\right)\right),\left(1,-\beta_{2} /\left(1-\alpha_{2}\right)\right)$, respectively.
} 
The unemployment rate (not in logs) is ${ }^{44}$

$$
u_{t}=l_{t}-n_{t}
$$

Note that unemployment stabilises in the long-run, i.e. $\Delta u^{L R}=0$, when $\Delta l^{L R}=$ $\Delta n^{L R}$. In other words, for unemployment stability in the long-run, the growth rate of employment should be equal to the growth rate of labour force, say $g$. We can also express the restriction in terms of the long-run growth rates of the exogenous variables:

$$
\frac{\beta_{1}}{1-\alpha_{1}} \Delta k^{L R}=\frac{\beta_{2}}{1-\alpha_{2}} \Delta z^{L R}=g
$$

Subtracting (32) from (31) and using the above restriction gives the following longrun unemployment rate equation:

$$
u^{L R}=\left[\frac{\beta_{2}}{1-\alpha_{2}} z_{t}^{L R}-\frac{\beta_{1}}{1-\alpha_{1}} k_{t}^{L R}\right]+\left[\frac{\left(\alpha_{1}-\alpha_{2}\right) g}{\left(1-\alpha_{1}\right)\left(1-\alpha_{2}\right)}\right],
$$

where the first term in square brackets measures the NRU and the second term captures frictional growth, i.e., the interplay between growth and the lagged adjustment processes.

The long-run value $\left(u^{L R}\right)$ towards which the unemployment rate converges reduces to the NRU only when frictional growth is zero - i.e. either when the exogenous variables do not grow or when the labour demand and supply equations have identical dynamic structures. Therefore, the NRU ceases to serve as an attractor for the unemployment rate under frictional growth. Frictional growth can arise only in interactive dynamics models. In the single equation models of the structuralist theory, the unemployment rate converges to the NRU. As explained in Section 2, this is given by the steady-state solution (6).

The second salient feature of the CRT is that it explicitly distinguishes between temporary and permanent shocks and defines measures for the after-effects of such shocks. ${ }^{45}$ For a temporary shock occurring at period $t$, unemployment persistence $(\sigma)$ is the sum of its responses for all periods in the aftermath of the shock $(t+j, j \geq 1)$ :

$$
\sigma \equiv \sum_{j=1}^{\infty} R_{t+j}^{u}
$$

where the series $R_{t+j}^{u}, j \geq 0$ defines the unemployment impulse response function to the

\footnotetext{
${ }^{44}$ Since labour force and employment are in logs, we can approximate the unemployment rate by their difference.

${ }^{45}$ See Karanassou and Snower (1998) for definitions of temporal as well as quantitative measures of persistence and responsiveness and their application. See also Pivetta and Reis (2004) for a discussion of various persistence measures.
} 
shock. ${ }^{46}$

If the unemployment rate model is static, then the shock is absorbed instantly and so persistence is zero $(\sigma=0)$. If it is dynamically stable, then the effects of the shock gradually die out and persistence is a finite quantity. Finally, if unemployment displays hysteresis, then the temporary shock has a permanent effect and thus $\sigma=\infty$.

On the other hand, unemployment responsiveness measures the cumulative unemployment effect of a permanent shock when unemployment does not adjust immediately to its new long-run equilibrium. In particular, suppose that the economy at period $t$, in an initial zero long-run equilibrium, ${ }^{47}$ is perturbed by a permanent unit shock. The unemployment responsiveness is the sum of the differences through time between the actual unemployment rate and the new (post-shock) long-run equilibrium unemployment rate:

$$
\rho \equiv \sum_{j=0}^{\infty}\left[R_{t+j}^{u}-1\right],
$$

If unemployment responds instantaneously to the shock and jumps to its new longrun equilibrium, then $\rho=0$, i.e. unemployment is perfectly responsive. If unemployment responds only gradually, so that the short-run unemployment effects of the shock are less than the long-run effect (undershooting), then unemployment is under-responsive and $\rho<0$. Finally, unemployment can overshoot its long-run equilibrium. If the total amount of overshooting exceeds the total amount of undershooting, then unemployment is over-responsive $(r>0)$.

The third salient feature of the CRT is the significant effect of capital stock on the long-run equilibrium of unemployment.

This is in sharp contrast to the influential form of the literature asserting that policies that shift upward the time path of capital stock have no long-run effect on the unemployment rate (see Layard, Nickell, and Jackman 1991). This view derives from the observation that the unemployment rate is trendless in the long-run. Other influential forms of the literature have dealt with this stylised fact in two ways. Phelps (1994, ch. 17), and Fitoussi et al. (2000) argue that the long-run unemployment rate can be influenced by trendless transformations of the capital stock (for example, the unemployment rate may depend on the capital labour ratio). This is also supported by Rowthorn (1999). ${ }^{48}$ Gordon (1997b) argues that a decrease in the growth rate of capital stock leads to an increase in the unemployment rate. Modigliani (2000) shows that there is a strong negative correlation between the investment and unemployment rates - this was

\footnotetext{
${ }^{46}$ In other words, $R_{t+j}^{u}, j \geq 0$, denote the coefficients of the infinite moving average representation of unemployment with respect to the shock.

${ }^{47}$ This assumption is only made for expositional simplicity.

${ }^{48} \mathrm{He}$ argues that the capital stock does not affect the long-run unemployment rate in the LayardNickell-Jackman model only because this model assumes a Cobb-Douglas production function, so that the elasticity of substitution between labour and capital is unity.
} 
dubbed the "Modigliani puzzle" by Blanchard (2000, p. 140). Blanchard (2005) claims that capital accumulation has influenced the evolution of European unemployment rate over three decades. On the other hand, Malley and Moutos (2001) show that unemployment rate is affected in the long-run when domestic and foreign capital stocks grow at unequal rates.

Karanassou and Snower (2004a) argue that there is no reason to believe that the labour market alone is responsible for ensuring that the unemployment rate is trendless in the long-run. In general, equilibrating mechanisms in the labour market and other markets are jointly responsible for this phenomenon. Thus restrictions on the relationships between the long-run growth rates (as opposed to the levels) of capital stock and other growing exogenous variables are sufficient for this purpose. ${ }^{49}$

\subsection{Comparing the Two Approaches}

As discussed in the previous sections, while the structuralist theory models the unemployment rate using traditional dynamics, the chain reaction theory uses interactive dynamics and derives the reduced form unemployment rate equation. In this context, the term "reduced form" means that the parameters of the equation are not estimated directly - they are simply some nonlinear function of the parameters of the underlying labour market system.

Generally, the ST postulates that the unemployment rate is a function of its own lags and a set of exogenous variables. Since the unemployment rate is a nontrended variable, the ST is restricted to use exogenous variables which do not display a trend. This restriction does not apply to the CRT - the only requirement is that each of the equations of the trended endogenous variables (e.g. employment, real wage, labour force, etc.) is balanced by the set of its explanatory variables.

A further constraint of the structuralist theory is that it cannot analyse the responses of unemployment to permanent shocks, since these are incompatible with the stationarity property of the exogenous variables.

Finally, it can be shown that if the ST single-equation model and each equation of the CRT multi-equation model have all identical regressors, then the two estimation procedures will yield identical results. ${ }^{50}$ In this case, it makes no difference whether one estimates unemployment rate directly via the ST single equation or via the reduced form equation of the CRT system.

However, in structural labour market systems, it is generally not the case that each constituent equation has the same regressors. Thus it becomes impossible for the regressors of the ST model to be identical with the regressors in each equation of the CRT

\footnotetext{
${ }^{49}$ As an example consider the above labour market model (29)-(30) and the restriction (34).

${ }^{50}$ See Karanassou, Sala, and Snower (2003b).
} 
model. Then the ST single-equation model can no longer be viewed as an unbiased summary of the CRT multi-equation model. Rather, the detailed economic interactions portrayed in the CRT model (including the dynamic interactions among the various lagged adjustment processes) can no longer be captured in the ST single-equation model.

Generally, the CRT postulates that the evolution of unemployment is driven by the interplay of lagged adjustment processes and the spillover effects within the labour market system. Spillover effects arise when shocks to a specific equation feed through the labour market system. The label "shocks" refers to changes in the exogenous variables.

To illustrate the workings of the CRT consider the following simple system of labour demand, wage setting, and labour supply equations: ${ }^{51}$

$$
\begin{aligned}
n_{t} & =\alpha_{1} n_{t-1}-\gamma w_{t}+\beta_{1} k_{t}, \\
w_{t} & =\alpha_{2} w_{t-1}-\delta u_{t}+\beta_{2} b_{t}, \\
l_{t} & =z_{t},
\end{aligned}
$$

where $n_{t}$ is employment, $w_{t}$ is real wage, and $l_{t}$ is labour force, the autoregressive parameters are $0<\alpha_{1}, \alpha_{2}<1, \gamma, \delta$, and $\beta$ 's are positive constants, $k_{t}$ is real capital stock, $b_{t}$ is real benefits, and $z_{t}$ is working age population. As in the previous section, all variables are in logs and we ignore the error terms for expositional ease. The unemployment rate is given by (33).

When $\gamma$ and $\delta$ are nonzero, all labour market shocks generate spillover effects. If $\delta=0$, i.e. unemployment does not influence wages, then labour demand and supply shocks do not spillover to wages. If $\gamma=0$, i.e. labour demand is completely inelastic with respect to wages, then shocks to wage setting do not spillover to unemployment. In this case, the influence of the exogenous variables $\left(k_{t}, b_{t}\right.$, and $\left.z_{t}\right)$ on unemployment can be measured through individual analysis of their respective equations. In other words, the main feedback mechanism in this model is provided by the wage elasticity of labour demand.

Let us rewrite the labour demand and real wage equations (38)-(39) as

$$
\begin{aligned}
& \left(1-\alpha_{1} B\right) n_{t}=-\gamma w_{t}+\beta_{1} k_{t}, \\
& \left(1-\alpha_{2} B\right) w_{t}=-\delta u_{t}+\beta_{2} b_{t},
\end{aligned}
$$

where $B$ is the backshift operator. Substitution of (42) into (41) gives

$$
\left(1-\alpha_{1} B\right)\left(1-\alpha_{2} B\right) n_{t}=\gamma \delta u_{t}+\left(1-\alpha_{2} B\right) \beta_{1} k_{t}-\gamma \beta_{2} b_{t} .
$$

\footnotetext{
${ }^{51}$ For more general models see Henry, Karanassou, and Snower (2000), and Karanassou, Sala, and Snower (2003b).
} 
Next, rewrite the labour supply (40) as

$$
\left(1-\alpha_{1} B\right)\left(1-\alpha_{2} B\right) l_{t}=\left(1-\alpha_{1} B\right)\left(1-\alpha_{2} B\right) z_{t}
$$

Finally, subtract from (44) the labour demand eq. (43) to get the reduced form unemployment rate equation:

$$
\left[\gamma \delta+\left(1-\alpha_{1} B\right)\left(1-\alpha_{2} B\right)\right] u_{t}=-\left(1-\alpha_{2} B\right) \beta_{1} k_{t}+\gamma \beta_{2} b_{t}+\left(1-\alpha_{1} B\right)\left(1-\alpha_{2} B\right) z_{t}
$$

Note that the above equation is dynamically stable since (i) products of polynomials in $B$ which satisfy the stability conditions are stable, and (ii) linear combinations of dynamically stable polynomials in $B$ are also stable.

Alternatively, the reduced form unemployment rate equation (45) can be written as

$$
u_{t}=\phi_{1} u_{t-1}-\phi_{2} u_{t-2}-\theta_{k 0} k_{t}+\theta_{b} b_{t}+\theta_{z} z_{t}+\theta_{k 1} k_{t-1}-\phi_{1} z_{t-1}+\phi_{2} z_{t-2}
$$

where $\phi_{1}=\frac{\alpha_{1}+\alpha_{2}}{1+\gamma \delta}, \phi_{2}=\frac{\alpha_{1} \alpha_{2}}{1+\gamma \delta}, \theta_{k 0}=\frac{\beta_{1}}{1+\gamma \delta}, \theta_{b}=\frac{\gamma \beta_{2}}{1+\gamma \delta}, \theta_{z}=\frac{1}{1+\gamma \delta}$ and $\theta_{k 1}=\frac{\alpha_{2}}{1+\gamma \delta}$.

The reduced form unemployment rate (46) portrays the following characteristics of the CRT. First, the autoregressive parameters $\phi_{1}$ and $\phi_{2}$ embody the interplay of the employment and wage setting adjustment processes $\left(\alpha_{1}\right.$ and $\alpha_{2}$, respectively).

Second, the coefficients $\theta_{k 0}, \theta_{b}$, and $\theta_{z}$ represent the short-run elasticities of unemployment with respect to capital stock, benefits, and working age population, respectively. The short-run elasticities are a function of the feedback mechanisms that give rise to the spillover effects.

Third, the lag structure of the shocks in the reduced form equation emphasizes the interplay of the lagged adjustment processes and the spillover effects.

A stationary, I(0), exogenous variable gives rise to a temporary shock and thus generates unemployment persistence which is measured by equation (36). It is important to note that the sum of persistence and the short-run elasticity gives the long-run elasticity of unemployment with respect to the specific variable. ${ }^{52}$

On the other hand, a nonstationary, I(1), exogenous variable gives rise to a permanent shock and thus generates unemployment responsiveness which is measured by equation (37).

Recall that, in applied work the NRU is the equilibrium unemployment rate at which there is no tendency for this rate to change at any time $t$, given the permanent component values of the levels/growth rates of the exogenous variables at that time (see

\footnotetext{
${ }^{52}$ This relation is a very handy way to compute numerically the long-run elasticities in an interactive dynamics model.
} 
Section 2). In this sense, it represents the unemployment that would be achieved once all the lagged adjustment processes have been completed in response to the permanent components of the exogenous variables.

Thus, the NRU is computed by setting $B$ equal to unity in the CRT equation (45):

$$
u_{t}^{n}=\frac{\left(\theta_{z}-\phi_{1}+\phi_{2}\right) \widetilde{z}_{t}+\theta_{b} \widetilde{b}_{t}-\left(\theta_{k 0}+\theta_{k 1}\right) \widetilde{k}_{t}}{1-\phi_{1}+\phi_{2}},
$$

where the $\sim$ above the variable denotes its permanent component. The estimates of the NRU will, by definition, reflect the interpretation of which changes in the exogenous variables were permanent and which were temporary.

Figure 1 below reproduces Graph 1 from Phelps and Zoega (1996) and Figure 5 from Henry, Karanassou, and Snower (2000) to illustrate the sharp disparity in the policy implications of the ST and CRT theories.

Phelps and Zoega (1996) apply the structuralist theory to worldwide data from 1957 to 1992, and find that the NRU is an attractor for the world actual unemployment rate (see Graph 1 in the left panel of Figure 1).

Henry, Karanassou, and Snower apply the chain reaction theory to UK data from 1964-1997, and argue that (a) the NRU was reasonably stable (around 4\%) over that period, and (b) the long swings in unemployment were due to prolonged after-effects of transitory but long-lasting shocks: the oil price shocks of the 70 s were responsible for the high unemployment rates of the $80 \mathrm{~s}$, whereas the slowdown of investment in the 90s led to the increase of unemployment during that period. (See Figure 5 in the right panel of Figure 1). Both of these results are clearly against the conventional wisdom that changes in unemployment are mainly caused by changes in the NRU, commonly due to changes in taxes, benefits, union power, and employment protection legislation.

\section{Figure 1}
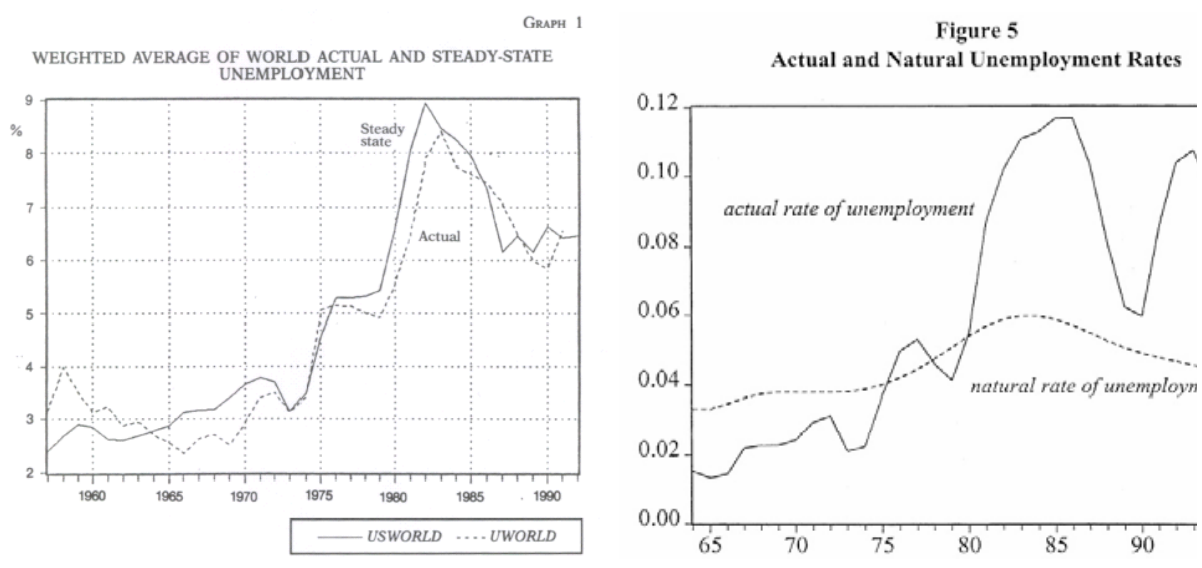
In short, whilst the structuralist theory relies on traditional dynamics (i.e. aggregative single-equation models) and thus focuses on the NRU, the chain reaction theory emphasizes the interplay between the dynamics of the labour market system and the trajectories of the exogenous variables, and states that the NRU ceases to function as a reference point (attractor) for the long-run unemployment rate.

In this section we presented arguments for the value added of the interactive dynamics approach in explaining the evolution of the unemployment rate. In what follows we show that a nonvertical PC emerges when nominal frictions interact with monetary growth and the interest rate is nonzero. We then propose an interactive dynamics framework for a holistic model of inflation and unemployment, i.e., a model that can jointly analyse the two phenomena.

\section{The Interaction between Monetary Growth and Nominal Frictions: The Frictional Growth NPC}

The standard and hybrid NPC models are becoming the new paradigm in modern monetary economics by steadily outplacing the traditional NAIRU models. The acceptance of the NPC as the new consensus rests primarily on two appealing features: (i) it derives from an economic rational and has solid microfoundations, and (ii) it is in line with the conventional wisdom of a vertical Phillips curve in the long-run.

The key element in deriving the properties of the New Phillips curve is the weight $\alpha$ in the wage and price staggering equations (24) and (26). When $\alpha=1 / 2$ the backwardand forward-looking components of the wage/price equation carry the same weight. We can thus say that when $\alpha \neq 1 / 2$, the wage/price setting behaviour displays intertemporal weighting asymmetry.

The fundamental principle of finance that "a dollar today worths more than a dollar tomorrow," implies that the coefficient $\alpha$ is a discounting parameter equal to $\frac{1+r}{2+r}$, where $r$ is the discount rate. This can be seen as follows. The one-period ahead wage $\left(W_{t+1}\right)$ needs to be discounted by the factor $\beta=\frac{1}{1+r}$ so that it is used in the wage-staggering equation (24) alongside with the wage set in the previous period $\left(W_{t-1}\right)$ that still applies in period $t$. Given that wage staggering requires that the wage set at period $t$ is a weighted average of past and future wages and their respective weights add up to $1+\beta$, we need to rescale them by the parameter $\alpha=\frac{1}{1+\beta}$ so that they add up to unity. It then follows that time discounting and a nonzero interest rate (so that $\beta<1$ and $\alpha>1 / 2$ ) give rise to an asymmetry in wage determination: the current wage $W_{t}$ is affected more strongly by the past wage $W_{t-1}$ than the future expected wage $E_{t} W_{t+1}$. 
This result is also well known from the microfoundations of Taylor-type contract equations under time discounting. Recent contributions to the microfoundations of wage-price setting under time-contingent staggered nominal contracts have shown that when agents discount the future (viz., they have a positive rate of time preference), then the backward-looking variables are weighted more heavily than the forward-looking ones, i.e. $\alpha>1 / 2{ }^{53}$ However, since the discount factor $\beta$ is almost unity, this result is largely ignored in the empirical and policy literature which sets $\alpha=1 / 2$ in the price staggering equation (26).

Nevertheless, the intertemporal weighting asymmetry cannot be dismissed as mere theoretical nicety as it plays a crucial dual role: (i) it generates inflation persistence, i.e. inflation is not a jump variable after all, and (ii) it gives rise to a long-run tradeoff between inflation and unemployment. ${ }^{54}$

\subsection{Price-Staggering and the "Forcing" Variable}

In the context of the simple, standard model of staggered price setting (26), the above points can be shown as follows. Let the "forcing" variable depend on real money balances: $:^{55}$

$$
x_{t}=M_{t}-P_{t}
$$

where $M_{t}$ denotes the log of money supply. Substituting this equation into equation (26), we obtain the following price equation: ${ }^{56}$

$$
P_{t}=\phi P_{t-1}+\theta E_{t} P_{t+1}+\left(\frac{\gamma}{1+\gamma}\right) M_{t}
$$

where $\phi=\frac{\alpha}{1+\gamma}$, and $\theta=\frac{1-\alpha}{1+\gamma}$.

To analyse inflation dynamics, it is convenient to rewrite the above price equation $\operatorname{as}^{57}$

$$
P_{t}=\lambda_{1} P_{t-1}+\frac{\gamma}{\lambda_{2}(1-\alpha)} \sum_{j=0}^{\infty}\left(\frac{1}{\lambda_{2}}\right)^{j} E_{t} M_{t+j},
$$

\footnotetext{
${ }^{53}$ Ascari (1998, 2000), Graham and Snower (2002, 2004), Helpman and Leiderman (1990), Huang and Liu (2002), and others.

${ }^{54}$ For a detailed analysis see Karanassou and Snower (2004b).

${ }^{55}$ This is in line with standard macro models.

${ }^{56}$ To derive this equation, observe that $P_{t}=\alpha P_{t-1}+(1-\alpha) E_{t} P_{t+1}+\gamma\left(M_{t}-P_{t}\right) \Rightarrow P_{t}=$ $\left(\frac{\alpha}{1+\gamma}\right) P_{t-1}+\left(\frac{1-\alpha}{1+\gamma}\right) E_{t} P_{t+1}+\left(\frac{\gamma}{1+\gamma}\right) M_{t}$.

${ }^{57}$ To see this, write $(49)$ as $\left(1-\lambda_{1} B\right)\left(1-\lambda_{2} B\right) E_{t} P_{t}=\frac{-\gamma B M_{t}}{(1-\alpha)}$, where $B$ is the backshift operator. This gives $\left(1-\lambda_{1} B\right) E_{t} P_{t}=\frac{\gamma}{\lambda_{2}(1-\alpha)} \sum_{j=0}^{\infty}\left(\frac{1}{\lambda_{2}}\right)^{j} E_{t} M_{t+j}$ which leads to (50) since $E_{t} P_{t}=P_{t}$.
} 
where $\lambda_{1}$ and $\lambda_{2}$ are the roots of equation (49), $0<\lambda_{1}<1$ and $\lambda_{2}>1 .^{58}$ In words, prices depend on past prices and expected future money supplies. Thus different stochastic monetary processes give rise to different price dynamics.

\subsection{Permanent Money Growth Shock}

For simplicity, let money growth be a random walk: ${ }^{59}$

$$
\mu_{t}=\mu_{t-1}+\varepsilon_{t}, \text { where } \varepsilon_{t} \sim \text { iid }\left(0, \sigma^{2}\right) .
$$

In this context, a one-off unit shock $\left(\varepsilon_{t}=1, \varepsilon_{t+j}=0\right.$ for $\left.j>0\right)$ translates to a permanent unit shift in money growth which, in the absence of money illusion, leads to a unit increase in the long-run inflation rate. ${ }^{60}$

By the price equation (50) and the random walk (52), we obtain the following price dynamics: ${ }^{61}$

$$
P_{t}=\lambda_{1} P_{t-1}+\left(1-\lambda_{1}\right) M_{t}+\left(\frac{1-\lambda_{1}}{\lambda_{2}-1}\right) \mu_{t},
$$

The associated closed form rational expectations solution of inflation is

$$
\pi_{t}=\lambda_{1} \pi_{t-1}+\left(1-\lambda_{1}\right) \mu_{t}+\left(\frac{1-\lambda_{1}}{\lambda_{2}-1}\right) \varepsilon_{t}
$$

The above equation is used to derive the impulse response function (IRF) of inflation.

\subsection{Inflation Dynamics}

It can be shown that the IRF of inflation to a permanent unit increase in money growth is:

$$
R_{t+j}^{\pi}=1-\lambda_{1}^{j}\left(1-\lambda_{1}\right)\left(\frac{2 \alpha-1}{\gamma}\right), j=0,1,2, \ldots,
$$

where $R_{t+j}^{\pi}$ denotes the period $t+j$ response of inflation to the shock. Note that in this simple price-staggering model, inflation under-shoots its new long-run equilibrium and

${ }^{58}$ In particular,

$$
\lambda_{1,2}=\frac{1 \mp \sqrt{1-4 \phi \theta}}{2 \theta}=\frac{1 \mp \sqrt{1-4 \frac{\alpha(1-\alpha)}{(1+\gamma)^{2}}}}{2\left(\frac{1-\alpha}{1+\gamma}\right)}
$$

\footnotetext{
${ }^{59}$ The qualitative conclusions of this analysis do not hinge on the random walk assumption. Any money growth process involving a permanent change in money growth (e.g. an $I(0)$ money growth process with a change in money growth regime, or a permanent change in the monetary authority's reaction function) would do.

${ }^{60}$ Note that a negative shock represents a sudden dissinflation.

${ }^{61}$ To see this, observe that $\sum_{j=0}^{\infty}\left(\frac{1}{\lambda_{2}}\right)^{j} E_{t} M_{t+j}=\left(\frac{\lambda_{2}}{\lambda_{2}-1}\right) M_{t}+\frac{\lambda_{2}}{\left(\lambda_{2}-1\right)^{2}} \mu_{t}$, and $\frac{\gamma}{\left(\lambda_{2}-1\right)(1-\alpha)}=1-\lambda_{1}$.
} 
gradually approaches it from below. ${ }^{62}$

In the case of a permanent shock, we measure "inflation persistence" along the lines of our responsiveness equation (37), i.e., as the cumulative inflation effect of the permanent unit money growth shock. In other words, "inflation persistence" is the combined amount of inflation under-shooting and inflation over-shooting:

$$
\begin{aligned}
\rho & \equiv \sum_{j=0}^{\infty}\left[R_{t+j}^{\pi}-1\right] \\
& =-\frac{2 \alpha-1}{\gamma}
\end{aligned}
$$

Note that a negative $\rho$ implies that the total amount of under-shooting exceeds the total amount of over-shooting.

The impulse response function (55) of the workhorse NPC model has the following interesting implications for inflation dynamics:

- If the discount rate $r$ is zero (i.e. $\beta=1$, so that $\alpha=1 / 2$ ), then inflation adjusts instantly to its new equilibrium. In other words, it is a jump variable, along the same lines as in the recent literature on "inflation persistence" under staggered nominal contracts.

- If the discount rate is positive (i.e. $\beta<1$, so that $\alpha>1 / 2$ ), then inflation is under-shooting. It gradually approaches its new equilibrium from below at a rate that depends on the autoregressive parameter $\lambda_{1}$.

Below we show that the combined amount of inflation under-shooting and overshooting is closely related to the slope of the long-run Phillips curve.

\subsection{The Slope of the Phillips Curve}

To derive the Phillips curve, recall that output (employment, unemployment rate) depends on real money balances (in equation (48)), which (by the price equation (53)) are

$$
x_{t} \equiv M_{t}-P_{t}=\lambda_{1}\left(M_{t-1}-P_{t-1}\right)+\left(1-\lambda_{1}\right)\left(\frac{2 \alpha-1}{\gamma}\right) \mu_{t}
$$

\footnotetext{
${ }^{62}$ Since $\alpha>1 / 2$ and $0<\lambda_{1}<1, R_{t+j}^{\pi}<1$ and $\lim _{j \rightarrow \infty} R_{t+j}^{\pi}=1$, i.e. the long-run inflation stabilises at the new level of money growth.

Karanassou and Snower (2004b) analyse models, within the NPC framework, where inflation can also over-shoot its new long-run equilibrium.
} 
In the long-run,

$$
\begin{aligned}
& x_{t}=\left(\frac{2 \alpha-1}{\gamma}\right) \pi_{t}, \text { or } \\
& u_{t}=-\left(\frac{2 \alpha-1}{\gamma}\right) \pi_{t} .
\end{aligned}
$$

(This is because the unemployment rate is negatively related to real money balances: $u_{t}=-\left(M_{t}-P_{t}\right)$.)

Therefore, the long-run Phillips curve is

$$
\pi_{t}=-\left(\frac{\gamma}{2 \alpha-1}\right) u_{t}
$$

since $\pi_{t}=\mu_{t}$ in the long-run. Observe that the slope of the long-run PC, $-\left(\frac{\gamma}{2 \alpha-1}\right)$, is simply the inverse of (56). That is, the slope of the Phillips curve is inversely related to the combined amount of inflation under-shooting and inflation over-shooting.

In the absence of time discounting $(\alpha=1 / 2)$, the long-run Phillips curve is vertical and inflation is a jump variable. This is an implausible, counter-factual special case, not just because there is no time discounting, but also because - as equation (57) shows it is not just the long-run Phillips curve that is vertical; the short-run Phillips curve is vertical as well.

By contrast, in the presence of time discounting $(\alpha>1 / 2)$, the long-run Phillips curve is downward-sloping and there is inflation persistence. The flatter is the long-run Phillips curve, the higher the under-shooting of inflation.

As already mentioned, it is often casually asserted that, since the discount factor is close to unity in practice, the long-run Phillips curve must be close to vertical. Inspection of the long-run Phillips curve (58), however, shows this presumption to be false. As we can see, the slope of this Phillips curve depends on both the discount parameter $\alpha$ and demand sensitivity parameter $\gamma$. Table 2 presents the slope for various common values of $\alpha$ and commonly estimated values of $\gamma^{63}$ It is clear that for a range of plausible parameter values the long-run Phillips curve is quite flat and, correspondingly, inflation displays significant under-shooting.

\footnotetext{
${ }^{63}$ Taylor (1980b) estimates it to be between 0.05 and 0.1 ; Sachs (1980) finds it in the range 0.07 and 0.1; Gordon (1982) gives an estimate of 0.1; Gali and Gertler (1999) estimate it to be between 0.007 and 0.047; calibration of microfounded models (e.g. Huang and Liu, 2002) assigns higher values. The discount rate applies to a period of analysis which is half the contract span.
} 
Table 2: Slope of the long-run Phillips curve

\begin{tabular}{|c|c|c|c|c|c|c|c|}
\hline \multirow[b]{2}{*}{$r(\%)$} & \multirow[b]{2}{*}{$\beta$} & \multirow[b]{2}{*}{$\alpha$} & \multicolumn{5}{|c|}{ slope } \\
\hline & & & $\gamma=0.01$ & $\gamma=0.02$ & $\gamma=0.05$ & $\gamma=0.07$ & $\gamma=0.10$ \\
\hline 1.0 & 0.990 & 0.502 & -2.01 & -4.02 & -10.1 & -14.1 & -20.1 \\
\hline 2.0 & 0.980 & 0.505 & -1.01 & -2.02 & -5.05 & -7.07 & -10.1 \\
\hline 3.0 & 0.971 & 0.507 & -0.68 & -1.35 & -3.38 & -4.74 & -6.77 \\
\hline 4.0 & 0.962 & 0.510 & -0.51 & -1.02 & -2.55 & -3.57 & -5.10 \\
\hline 5.0 & 0.953 & 0.512 & -0.41 & -0.82 & -2.05 & -2.87 & -4.10 \\
\hline
\end{tabular}

Table 3 summarises the properties of the standard and frictional growth NPC models.

Table 3: Inflation dynamics and the slope of the PC

\begin{tabular}{|lc|c|c|c|}
\hline & & $\begin{array}{c}\text { Inflation } \\
\text { dynamics }\end{array}$ & $\begin{array}{c}\text { Long-run } \\
\text { Phillips curve }\end{array}$ & $\begin{array}{c}\text { Short-run } \\
\text { Phillips curve }\end{array}$ \\
\hline NPC & $\alpha=\frac{1}{2}$ & jump variable & vertical & vertical \\
\hline FG-NPC & $\alpha>\frac{1}{2}$ & under-shooting & $\begin{array}{c}\text { downward- } \\
\text { sloping }\end{array}$ & $\begin{array}{c}\text { downward- } \\
\text { sloping }\end{array}$ \\
\hline
\end{tabular}

Our analysis calls into question the conventional view that the long-run Phillips curve is either vertical or nearly vertical and that forward-looking Phillips curves are difficult to reconcile with substantial inflation persistence. The intertemporal weighting asymmetry of the FG-NPC model allows the interplay of frictions (nominal staggering) and growth (permanent shocks) to generate sufficient inflation persistence and produce an inflation-unemployment tradeoff both in the short- and long-run. This result implies that the two phenomena can be better understood when analysed within the same framework than when studied by separate models.

\section{A Holistic Model for Inflation and Unemployment}

The previous sections provide the following insights for the development of a holistic model for inflation and unemployment:

- The Phillips curve portrays the relation between the reactions of inflation and unemployment to a monetary shock. In particular, the PC is the ratio of the impulse response functions (IRFs) of inflation and unemployment with respect to a permanent monetary change. This implies that PC tradeoffs cannot be adequately captured by a single dynamic equation.

- The interplay between monetary changes and nominal frictions, and the phenomenon of frictional growth can be assessed by estimating a holistic model, containing wage-price equations as well as real equations. The nominal wage-price equations are to describe how the nominal variables depend on the money supply and, via 
the nominal frictions, on the past and future nominal variables. Then, in the presence of frictional growth, money growth shocks lead to changes in the relative magnitudes of nominal variables, such as changes in real money balances or changes in the real wage. On this basis, the real equations are to describe how real variables, such as unemployment, respond to these changes in the relations among nominal variables.

- The relation of wages and prices to their past and expected future values may be expressed in terms of nominal equations that are backward-looking. The reason, as shown above, is that when the rational expectations solution of the price equation is derived, the expected future values of nominal variables can be expressed in terms of current and past endogenous variables.

To illustrate our holistic approach, we consider the model estimated by Karanassou, Sala, and Snower (2005) for the US over the 1963-2000 period. This interactive dynamics model consists of three equations - unemployment rate, price level, and nominal wage - and contains no money illusion, no permanent nominal rigidities, and no departure from rational expectations. We briefly describe the model below:

1. The unemployment rate is a function of its lags, real money balances, investment, trade deficit, oil price, financial wealth, and social security contributions.

2. The price level depends on its lagged values, money supply, wages, unemployment rate, productivity, oil price, and indirect taxes.

3. The nominal wage depends on its lags, price level, money supply, unemployment rate, productivity, and benefits.

The wage and price setting equations portray nominal sluggishness (so that changes in money growth lead to changes in real money balances), and the unemployment equation indicates how the changes in real money balances affect the unemployment rate. Figure 2 shows that the model tracks the data very well.

Figure 2. Actual and fitted values.

a. Unemployment rate

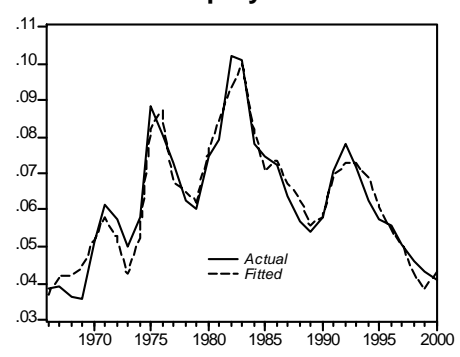

b. Inflation

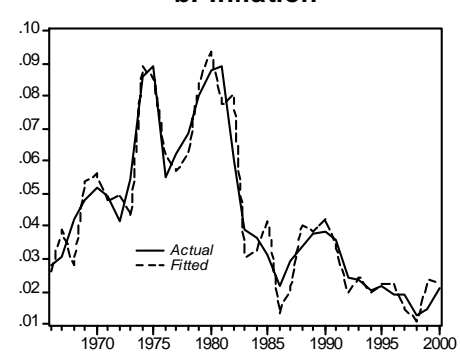

c. Real wage

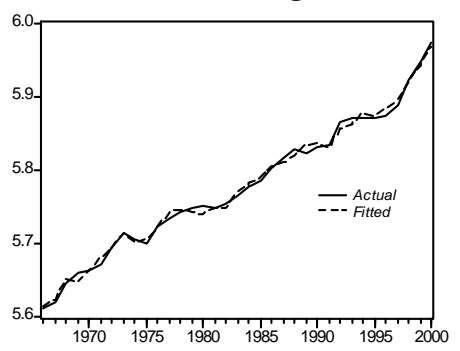


A permanent money growth shock is introduced by adding equation (52) to the above three-equation system. The model is then solved to derive the impulse response functions (IRFs) of inflation and unempoyment and the implied inflation-unemployment tradeoff. These are presented in Figure 3.

Figure 3. Impulse response functions

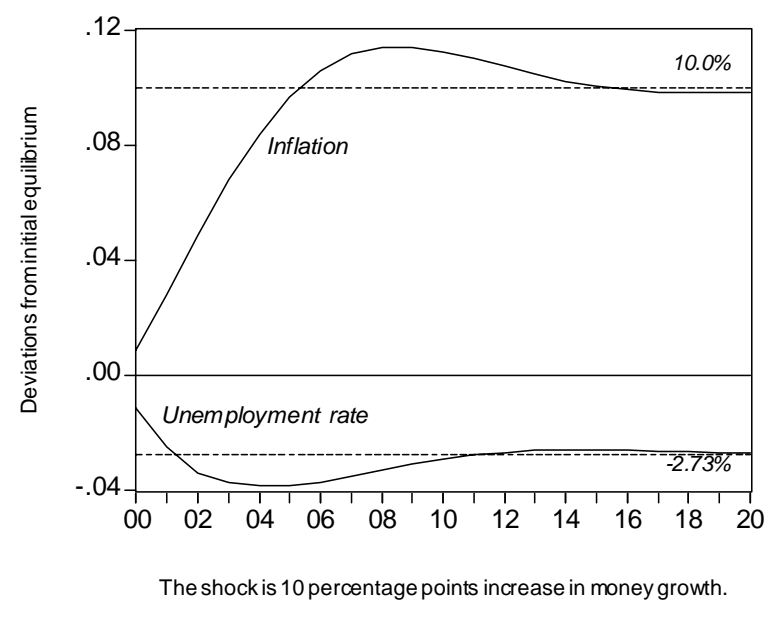

The inflation IRF has all the desirable properties: the influence of the monetary shock on inflation is delayed and gradual, and in the long run inflation is equal to money growth. The unemployment IRF also exhibits plausible behaviour: the unemployment effect of the monetary shock is also delayed and gradual, but this effect occurs sooner than the inflation effect (e.g. the maximum unemployment effect occurs well before that on inflation).

Both inflation and unemployment responses take a long time to converge to their long-run values. The only strikingly unconventional property of the unemployment IRF is that the unemployment effect does not die down to zero; rather, a 10 percentage points (pp) increase in money growth leads to a $2.73 \mathrm{pp}$ fall in long-run unemployment. Thus, the slope of the long-run Phillips curve is $-3.66\left(=\frac{10}{-2.73}\right)$.

In addition to the Phillips curve effects, the above model can be used to explain the evolution of the US unemployment rate. Consider the puzzling U.S. macroeconomic developments of the 90s, when the unemployment rate declined (after 1992) and inflation remained subdued even though the rate of money growth surged. (The money growth rate was less than 2 percent per annum in 1993, rose steadily to over 8 percent in 1998, before declining beneath 6 percent in 2000.) We conduct the following accounting exercises: in Figures 4a-b money growth is fixed at its 1993 rate, in Figures 4c-d productivity growth is fixed at its 1993 rate. 


\section{Figure 4}

a. Money growth and unemployment

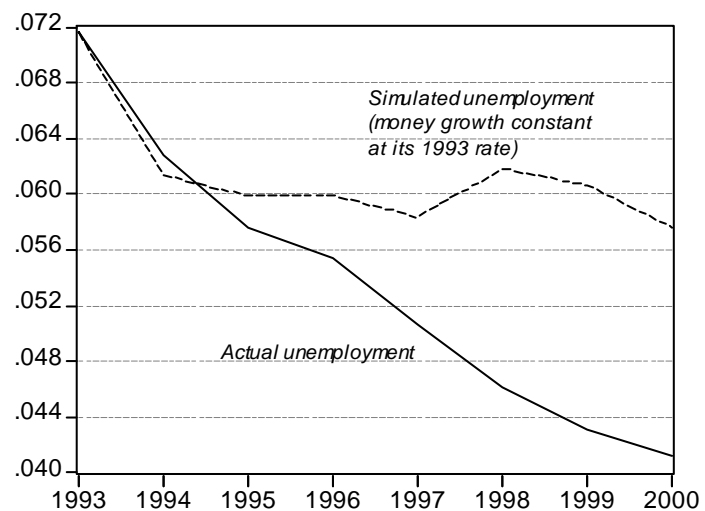

c. Productivity growth and unemployment

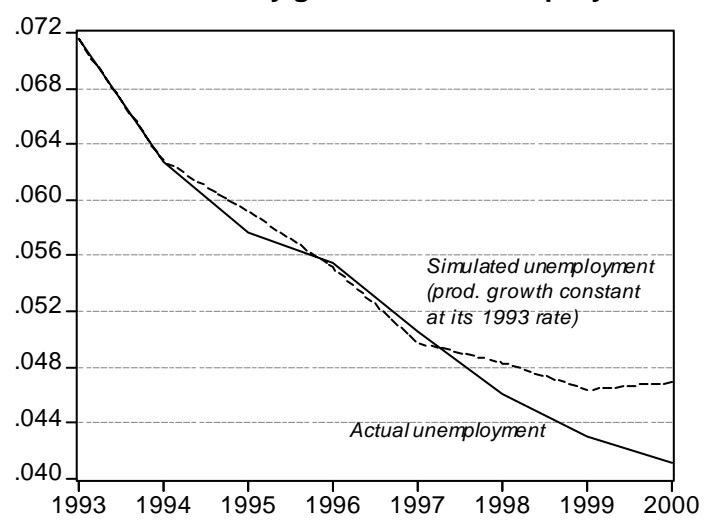

b. Money growth and inflation

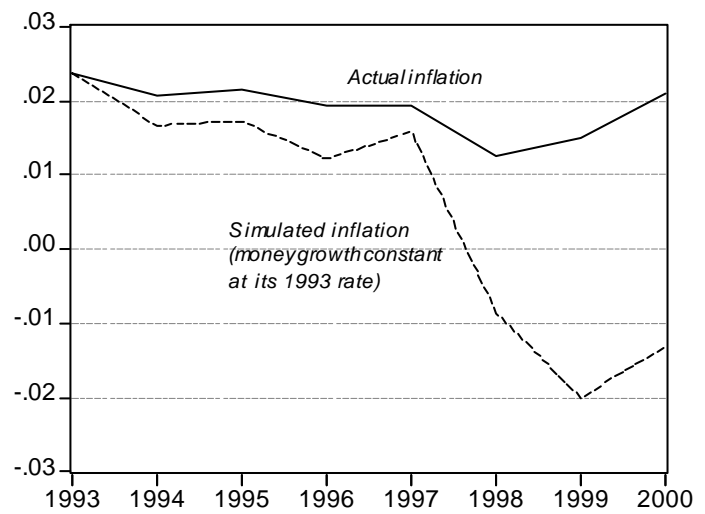

d. Productivity growth and inflation

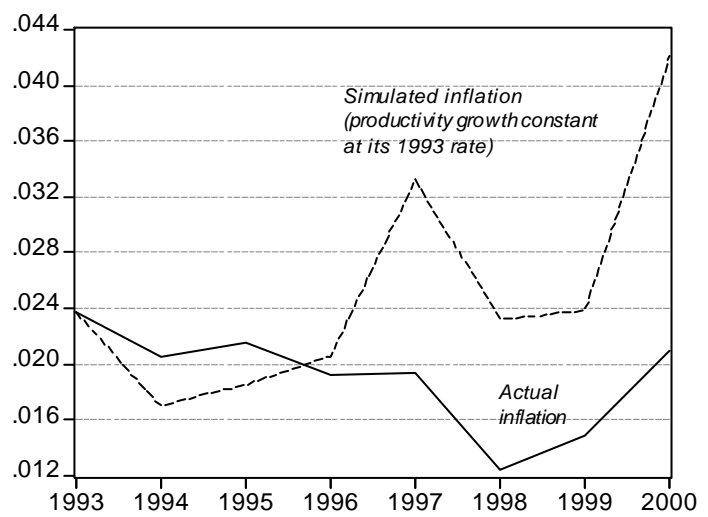

First, the surge of money growth over the second half of the 90s can account for over a half of the decline in unemployment over this period (Figure 4a). Second, the money growth surge was of course associated with a rise in inflation (Figure 4b). But, third, this inflationary influence was substantially undone by the fall in inflation associated with the increase in productivity growth over the period (Figure 4d). Finally, the contribution of productivity growth to the fall in unemployment is modest: around $20 \%$ of the overall decrease in unemployment over the period (Figure 4c).

The above interactive dynamics framework can be expanded by endogenising more real variables (e.g. productivity), and the analysis can be extended to include the influence of other variables (e.g. trade deficit, budget deficit) on both inflation and unemployment. 


\section{Conclusions}

The orthodox view that there is no long-run relationship between inflation and unemployment has implied that the evolution of inflation and unemployment can be adequately modeled by separate economic branches. These branches comply with a vertical $\mathrm{PC}$ and the existence of a natural rate of unemployment.

In particular, the inflation dynamics macro branch takes for granted the existence of the NRU and estimates the unemployment rate compatible with inflation stability the NAIRU. The labour macro branch takes for granted the existence of the NAIRU, and tries to identify the real economic forces that drive the NRU.

So speaking, the conventional inflation dynamics and unemployment rate models can be viewed as the two sides of the same coin - the coin of the classical dichotomy.

In this paper we overviewed the literature of the Phillips curve and critically assessed the restrictions that need to be imposed so that its models predict a zero inflationunemployment tradeoff, at least in the long-run.

We showed that the orthodox view that the long-run NPC is either vertical or nearly vertical and that forward-looking Phillips curves are difficult to reconcile with substantial inflation persistence relies on the implausible assumption of intertemporal weighting symmetry (symmetric backward- and forward-looking elements in the price-setting behaviour due to no time discounting).

We then demonstrated that when intertemporal weighting asymmetry is introduced in the NPC, the resulting model allows the interplay of frictions (nominal staggering) and growth (permanent shocks) to generate sufficient inflation persistence and produce an inflation-unemployment tradeoff in both the short- and long-runs. We call this model the frictional growth NPC and, like the standard NPC, it contains no money illusion, no permanent nominal rigidities, and no departure from rational expectations.

We also discussed the traditional dynamics (single equation) and interactive dynamics (multi-equation) unemployment rate models and argued in favour of an interactive dynamics labour market model.

Our analysis calls for the adoption of a holistic framework that can jointly model inflation dynamics, estimate the inflation-unemployment tradeoff, and determine the factors responsible for the movements of the long-run equilibrium unemployment rate. We argue that an interactive dynamics model that includes wage-price setting equations and labour market ones can jointly evaluate Phillips curve effects and identify the temporary and permanent shocks that give rise to the observed unemployment rate trajectory. 


\section{References}

[1] Ahmed, S., and J. H. Rogers (2000): "Inflation and the great ratios: Long-term evidence from the U.S.," Journal of Monetary Economics, 45, 3-35.

[2] Akerlof, G.A., W.T. Dickens, and G. L. Perry (1996): "The Macroeconomics of Low Inflation," Brookings Papers on Economic Activity, 1:1996, pp. 1-76.

[3] Akerlof, G.A., W.T. Dickens, and G. L. Perry (2000): "Near-Rational Wage and Price Setting and the Long-Run Phillips Curve," Brookings Papers on Economic Activity, 1:2000, pp. $1-60$.

[4] Ascari, G. (1998): "Superneutrality of money in staggered wage-setting models," Macroeconomic Dynamics, ${ }^{o} 2$, pp. 383-400.

[5] Ascari, G. (2000): "Optimising agents, staggered wages and persistence in the real effects of monetary shocks," The Economic Journal, 110, July, pp. 664-686.

[6] Ball, L. (1997): "Disinflation and the NAIRU," in C.D. Romer and D.H. Romer (eds.), Reducing Inflation: Motivation and Strategy, Chicago: University of Chicago Press, pp. 167-194.

[7] Ball, L. (1999): "Aggregate demand and long-run unemployment," Brooking Papers on Economic Activity, 2:1999, pp. 189-251.

[8] Bande, R., and M. Karanassou (2006): "Labour Market Flexibility and Regional Unemployment Rate Dynamics: Spain 1980-1995", mimeo.

[9] Blanchard, O. (2000): "The Economics of Unemployment: shocks, Institutions and Interactions," Lionel Robins Lectures.

[10] Blanchard, O. (2005): "Monetary Policy and Unemployment," in Monetary Policy and Unemployment - US, Euro-Area, and Japan, W. Semmler (ed.), Routledge, London.

[11] Bårdsen, G., E. Jansen, and R. Nymoen (2002), "The Empirical (Ir)relevance of the New Keynesian Phillips Curve," Norwegian University of Science and Technology, Working Paper Series No. 21/2002.

[12] Bårdsen, G., E. Jansen, and R. Nymoen (2004), "Econometric Evaluation of the New Keynesian Phillips Curve," Oxford Bulletin of Economics and Statistics, 66, 671-686.

[13] Bernanke, B. and I. Mihov (1998): "The Liquidity Effect and Long-Run Neutrality," Carnegie-Rochester Conference Series on PublicPolicy, vol. 49, 1, pp. 149-94.

[14] Bullard, J., and J. W. Keating (1995): "The long-run relationship between inflation and output in postwar economies," Journal of Monetary Economics, 36, pp. 477-496.

[15] Calvo, G. A. (1983): "Staggered Prices in a Utility-Maximizing Framework," Journal of Monetary Economics, 12(3), 383-398.

[16] Campbell, J. and G.N. Mankiw (1987): "Are Output Fluctuations Transitory?," Quarterly Journal of Economics, pp. 857-880. 
[17] Coakley, J., A. M. Fuertes, and G. Zoega (2001): "Evaluating the Persistence and Structuralist Theories of Unemployment," Studies in Nonlinear Dynamics and Econometrics, 5 (3), pp. 179-202.

[18] Clarida, R., J. Galí and M. Gertler (1999): "The science of monetary policy: A New Keynesian perspective," Journal of Economic Literature, 37, December, pp. 1661-1707.

[19] Dolado, J.J., J.D. López-Salido and J.L. Vega (2000): "Unemployment and inflation persistence in Spain: Are there Phillips tradeoffs?" Spanish Economic Review, 2, pp. 267-291.

[20] Fair, R.C. (2000): "Testing the NAIRU Model for the United States," The Review of Economics and Statistics, pp. 64-71.

[21] Fisher, M.E. and J.J. Seater (1993): "Long-run neutrality and supeneutrality in an ARIMA framework," American Economic Review, 83, pp. 402-415.

[22] Fitoussi, J.P., D. Jestaz, E.S. Phelps and G. Zoega (2000): "Roots of Recent Recoveries: Labor Reforms or Private sector Forces," Brooking Papers on Economic Activity, 1:2000, pp. 292-304.

[23] Fuhrer, J. C. and G. Moore: (1995): "Inflation Persistence," The Quarterly Journal of Economics, CX, pp. 127-160.

[24] Fuhrer, J. C. (1997): "The (Un)Importance of Forward-Looking Behavior in Price Specifications," Journal of Money, Credit, and Banking, 29 (3), pp.338-350.

[25] Galí, J. (2003): "New Perspectives on Monetary Policy, Inflation, and the Business Cycle," in Advances in Economic Theory, M. Dewatripont, L. Hansen, and S.T. Turnovsky (eds), vol. III, Cambridge University Press, pp. 151-197.

[26] Galí, J. and M. Gertler (1999): "Inflation dynamics: a structural econometric analysis," Journal of Monetary Economics, 44, pp. 195-222.

[27] Galí, J., M. Gertler and J.D. López-Salido (2001): "European inflation dynamics," European Economic review, 45, pp. 1237-1270.

[28] Goodfriend, M. and R.G. King (1997): "The new neoclassical synthesis and the role of monetary policy," NBER Macroeconomics Annual, pp. 231-295.

[29] Gordon, R. J. (1982): Price Inertia and Policy ineffectiveness in the United States, 18901980. Journal of Political Economy, 90(6), 1087-1117.

[30] Gordon, R. J. (1983): "A century of evidence on wage and price stickiness in the United States, the United Kingdom, and Japan" in Macroeconomics, prices, and quantities, J. Tobin (Ed.), Washington, D.C.: Brookings Institution, pp. 85-121.

[31] Gordon, R.J. (1990): "What is New-Keynesian Economics?" Journal of Economic Literature, vol. 28, 3, september, pp. 1115-1171.

[32] Gordon, R.J. (1997a): "The Time-Varying NAIRU and Its Implications for Economic Policy," Journal of Economic Perspectives, vol. 11, 1, pp. 11-32. 
[33] Gordon, R.J. (1997b): "Is there a trade-off between unemployment and productivity growth," in D.J. Snower and G. de la Dehesa (eds), Unemployment Policy: Government Options for the Labour Market, CU Press, Cambridge.

[34] Gordon, R.J. (1998): "Foundations of the Goldilocks economy: supply shocks and the Time-Varying NAIRU," Brooking Papers on Economic Activity, 2: 1998, pp. 297-346.

[35] Graham, L. and D.J. Snower (2002): "The return of the long-run Phillips curve," CEPR Discussion Paper 3691, Centre for Economic Policy Research, London; IZA Discussion Paper 646, Institute for the Study of Labor, Bonn.

[36] Graham, L. and D.J. Snower (2004): "The real effects of money growth in dynamic equilibrium," ECB Working Paper, no 412, European Central Bank, Frankfurt.

[37] Grier, K. B., and M. J. Perry (1998): "On Inflation and Inflation Uncertainty in the G7 countries," Journal of International Money and Finance, 17, pp. 671-689.

[38] Helpman, E. and L. Leiderman (1990): "Real wages, monetary accommodation, and inflation," European Economic Review, 34, pp. 897-911.

[39] Henry, S.G.B., M. Karanassou and D.J. Snower (2000): "Adjustment Dynamics and the Natural Rate," Oxford Economic Papers, 52, pp. 178-203.

[40] Huang, K.X.D. and Z. Liu (2002): "Staggered price-setting, staggered wage-setting and business cycle persistence," Journal of Monetary Economics, 49, pp. 405-433.

[41] Karanassou, M. and D.J. Snower (1997): "Is the natural rate a reference point?," European Economic Review, 41, pp. 559-569.

[42] Karanassou, M. and D. J. Snower (1996), "Explaining Disparities in Unemployment Dynamics" in Baldassari M., L. Paganetto, and E.S. Phelps (eds), The 1990's Slump: Causes and Cures, Macmillan Press and Rivista di Politica Economica.

[43] Karanassou, M. and D.J. Snower (1998): "How Labor Market Flexibility Affects Unemployment: Long-Term Implications of the Chain Reaction Theory," The Economic Journal, 108, May, pp. 832-849.

[44] Karanassou, M. and D.J. Snower (2004a): "Unemployment Invariance ", German Economic Review, 5(3), 297-317.

[45] Karanassou, M. and D.J. Snower (2004b): "Inflation Persistence Revisited," Queen Mary Working Paper, 518, University of London, London.

[46] Karanassou, M., H. Sala and D.J. Snower (2002): "Long-run inflation-unemployment dynamics: The Spanish Phillips curve and economic policy," IZA Discussion Paper, 645, IZA, Bonn.

[47] Karanassou, M., H. Sala and D.J. Snower (2003a): "Unemployment in the European Union: A Dynamic Reappraisal," Economic Modelling, 20, pp. 237-273.

[48] Karanassou, M., H. Sala and D.J. Snower (2003b): "The European Phillips curve: Does the NAIRU exist?" Applied Economics Quarterly, vol. 49, 2, pp. 93-121. 
[49] Karanassou, M., H. Sala and D.J. Snower (2004): "Unemployment in the European Union: Institutions, Prices and Growth," CESifo Working Paper Series, 1247, Munich.

[50] Karanassou, M., H. Sala and D.J. Snower (2005): "A Reappraisal of the InflationUnemployment tradeoff," European Journal of Political Economy, vol. 21, 1, pp. 1-32.

[51] King, R.G. and M.W. Watson (1994): "The post-war U.S. Phillips curve: a revisionist econometric history," Carnegie-Rochester Conference Series on Public Policy, 41, pp. $157-219$.

[52] Layard, R., S. Nickell, and R. Jackman (1991), Unemployment: Macroeconomic Performance and the Labour Market, Oxford: Oxford University Press.

[53] Malley, J., and T. Moutos (2001): "Capital Accumulation and Unemployment: A Tale of Two Continents," Scandinavian Journal of Economics, 103 (1), pp. 79-99.

[54] Mankiw, N.G. (2001): "The inexorable and mysterious tradeoff between inflation and unemployment," The Economic Journal, 111, pp. C45-C61.

[55] Mankiw, N.G. and R. Reis (2002): "Sticky information versus sticky prices: a proposal to replace the New Keynesian Phillips curve," The Quarterly Journal of Economics, 117(4), pp. 1295-1328.

[56] Modigliani, F. (2000): "Europe's economic problems," Prepared for testimony before the Monetary Committee of the European Parliament.

[57] Modigliani, F. and L. Papademos (1976): "Monetary policy for the coming quarters: The conflicting views," The New England Economic Review, 1976, pp. 2-35. Reprinted in The Collected Papers of Franco Modigliani (1980), 3, pp. 186-219, MIT Press: Cambridge Mass.

[58] Phelps, E. S. (1978), Disinflation without Recession: Adaptive Guideposts and Monetary Policy, Weltwirtschaftliches Archiv, C, 239-265.

[59] Phelps, E. S. (1994): Structural Booms: The Modern Equilibrium Theory of Unemployment, Interest and Assets, Harvard University Press, Cambridge (MA).

[60] Phelps, E.S. (1999): "Behind this structural boom: the role of asset valuations," The American Economic Review, Papers and Proceedings, vol. 89, 2, May, pp. 63-68.

[61] Phelps, E. and G. Zoega (1996): "Do the main structural forces of the 1970s and 1980s account for the 90s slump as well?," in M. Baldassari, L. Paganetto and E. S. Phelps (eds), The 90s Slump: Causes and Cures, MacMillan Press, London.

[62] Phelps, E. and G. Zoega (1997): "The rise and downward trend of the natural rate," American Economic Review Papers and Proceedings, pp. 283-289.

[63] Phelps, E. and G. Zoega (1998): "Natural rate theory and OECD unemployment," The Economic Journal, vol. 108, pp. 782-801.

[64] Phelps, E. and G. Zoega (2001): "Structural booms: productivity expectations and asset valuations," Economic Policy, 32, April, pp. 85-126. 
[65] Pivetta, F., and R. Reis (2004): "The Persistence of Inflation in the United States," manuscript, Harvard University.

[66] Roberts, J.M. (1995): "New Keynesian Economics and the Phillips curve," Journal of Money, Credit and Banking, 27 (4,1), 975-984.

[67] Rotemberg, J. (1982), "Monopolistic Price Adjustment and Aggregate Output," Review of Economic Studies, 44, 517-531.

[68] Rowthorn, R. (1999), "Unemployment,wage bargaining and capital-labour substitution," Cambridge Journal of Economics, 23, 413-425.

[69] Rudd, J. and K. Whelan (2005): "New Tests of the New-Keynesian Phillips Curve," Journal of Monetary Economics, 52 (6), 1167-1181.

[70] Rudebusch, G. D. and L.E.O. Svensson (1999): "Policy rules for inflation targeting," in Monetary Policy Rules, edited by J.B. Taylor, The University of Chicago Press, 203-246.

[71] Sachs, J. (1980): “The changing cyclical behavior of wages and prices: 1890-1976," American Economic Review, 70, 78-90.

[72] Staiger, D., J.H. Stock and M. Watson (1997a): "How Precise are Estimates of the Natural Rate of Unemployment," in C. Romer and D. Romer (eds.), Reducing Inflation: Motivation and Strategy, University of Chicago Press.

[73] Staiger, D., J.H. Stock and M. Watson (1997b): "The NAIRU, Unemployment and Monetary Policy," Journal of Economic Perspectives, vol. 11, no 1, pp. 33-49.

[74] Svensson, L.E.O. (2000): "Open economy inflation targeting," Journal of International Economics, 50, pp. 155-183.

[75] Taylor, J.B. (1979), "Staggered Wage Setting in a Macro Model," American Economic Review, No. 69, May, pp. 108-113.

[76] Taylor, J.B. (1980a): "Aggregate Dynamics and Staggered Contracts," Journal of Political Economy, Vol. 88 (1), February, pp. 1-23.

[77] Taylor, J. B. (1980b), "Output and Price Stability: An International Comparison," Journal of Economic Dynamics and Control, 2, 109-132.

[78] Tobin, J. (1998): "Supply constraints on employment and output: NAIRU versus natural rate," International Conference in Memory of Fausto Vicarelli, Rome, Nov 21-23. 